\title{
Molecular and morphological revision of Afrotropical Hypoborini (Coleoptera: Curculionidae: Scolytinae) revealed novel bark beetle taxa with narrow geographical distributions
}

\author{
BJARTE H. JORDAL \\ University Museum of Bergen, University of Bergen, PB 7800, 5007 Bergen, Norway; e-mail: bjarte.jordal@uib.no \\ ORCiD. 0000-0001-6082-443X
}

\begin{abstract}
Key words. Curculionidae, Scolytinae, Hypoborini, bark beetles, molecular phylogeny, identification key, biogeography, new tribe, new subtribe, new genera, new species, Afrotropical Region, Madagascar
\end{abstract}

\begin{abstract}
Species in the bark beetle tribe Hypoborini Nüsslin, 1912 occur in dead twigs and branches, mainly in dry forest. The Afrotropical fauna previously included ten species in five genera. A taxonomic revision based on molecular and morphological data supports the description of three new genera and seven new species, and the creation of a new subtribe Xerasiborina Jordal, subtrib. $\mathrm{n}$. in order to take account of the difference between crested and non-crested (elytral base) hypoborines. The new subtribe includes Xerasiborus Jordal, gen. n., Nisiborus Jordal, gen. n. and tentatively Glochiphorus Strohmeyer, 1910. Hypoborina in the Afrotropical region includes Dacryostactus Schaufuss, 1905, Styracoptinus Wood, 1962, Afrotrypetus Bright, 1982 stat. res., and Corditarsus Jordal, gen. n., with Hypoborus Erichson, 1836 and Liparthrum Wollaston, 1854 as geographically close members in the warm Palearctic. New species described are Xerasiborus quadrituberculatus Jordal, sp. n., Xerasiborus bituberculatus Jordal, sp. n., Xerasiborus euphorbiae Jordal, sp. n. and Xerasiborus asperatus Jordal, sp. n., all from Madagascar, Xerasiborus zambesianus Jordal, sp. n. from Tanzania, Nisiborus schaufussi Jordal, sp. n. from Madagascar and Afrotrypetus capensis Jordal, sp. n. from South Africa. New combinations include Nisiborus hylesiniformis (Schedl, 1961), comb. n. (from Cryphyophthorus Schedl, 1953), Corditarsus australis (Schedl, 1975) comb. n. (from Liparthrum), Corditarsus tanganyikaensis (Schedl, 1972) comb. n. (from Hypoborus) and Afrotrypetus euphorbiae Bright, 1981 comb. res. (from Styracoptinus). Three genera were removed from Hypoborini: Chaetophloeus LeConte, 1876 and placed in Chaetophloeini Jordal, trib. n., Zygophloeus Schedl, 1958 in Hylesinini Erichson, 1836 and Cryphyophthorus Schedl, 1953 as a genus incertae sedis. Biogeographical analyses indicate an early Palaeocene origin of Hypoborini, with an ancestral area split between Asia/Africa and Madagascar. Only a single colonization of Madagascar occurred, with a single recolonization of the African mainland. The more species-rich Mediterranean and Macaronesian radiation in Liparthrum occurred later in the Oligocene, most likely prior to the origin of the Atlantic islands.
\end{abstract}

ZooBank Article Registration: http://zoobank.org/urn:Isid:zoobank.org:pub:2C8AA3C2-FEF7-40B9-9667-D484C6184A64

\section{INTRODUCTION}

Bark beetles in the tribe Hypoborini Nüsslin, 1912 mainly occur in the Afrotropical and warm Mediterranean part of the Palearctic, with some species occurring in the drier parts of the Americas and SE-Asia. None of the species are regarded as pests and most are rarely collected. As typical inhabitants of dry and sun-exposed twigs and branches it is likely they are not of interest for the average bark beetle collector. This lineage is not as species rich as another group, which shares a preference for similar habitats, the Micracidini LeConte, 1876 (see Jordal, 2021). However, they are particularly speciose in a Mediterranean lineage of Liparthrum, which radiated onto the Macaronesian islands during the Miocene (Jordal et al., 2004).

The Hypoborini (Table 1) are characteristic and fairly easy to recognize, even though most species are very small.
Most genera have a raised crest along the basal margin of the elytra, interstrial setae that are short and scale-like and in single rows, while additional ground vestiture consists of scattered white, recumbent setae. Chaetophloeus and Zygophloeus are questionable members of this tribe and are both placed far from the core Hypoborini in recent molecular phylogenetic analyses (Jordal \& Cognato, 2012; Johnson et al., 2018; Pistone et al., 2018). There is some indication that Hypoborini are most closely related to Micracidini (Jordal \& Kaidel, 2017), but at best the relationship is very distant. Both groups of bark beetles are found in the Afrotropical and Neotropical (and Nearctic) regions, typically where climates are arid, with Hypoborini taxa as the most extreme of the two groups.

This work concentrates on the fauna in the Afrotropical region, which is the major area for Hypoborini evolution. 
Table 1. Previous and current classification of Hypoborini. Taxa in blue are moved from the tribe Hypoborini or to a new subtribe Xerasiborina.

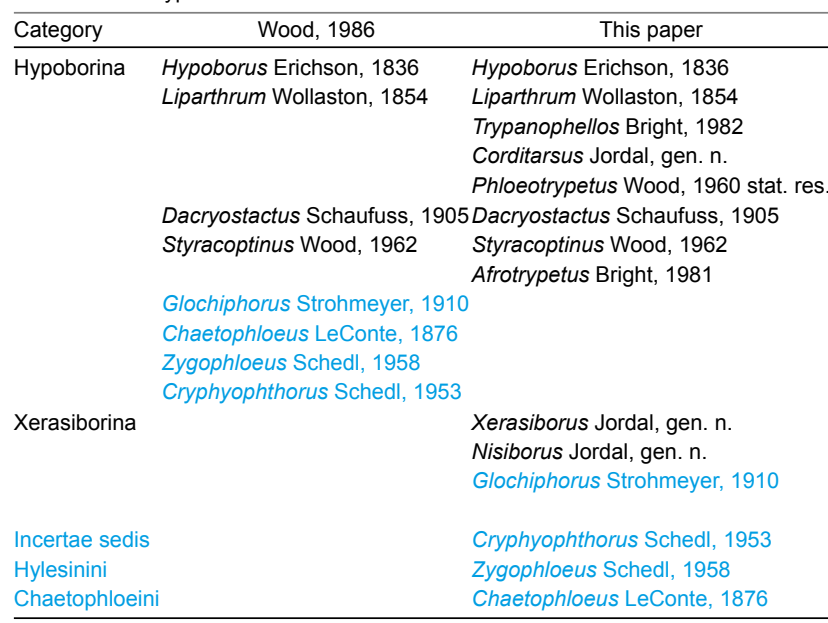

Several new genera were discovered during recent inventories in Madagascar and southern parts of Africa. The recent collecting of fresh samples has also made it possible to test hypotheses on phylogenetic relationship using molecular markers. A new framework for the classification of Hypoborini is presented here based on molecular and morphological data along with a biogeographical analysis of their origin and historical distribution.

\section{MATERIAL AND METHODS}

Specimens examined were collected mainly by the author and staff during an inventory of the biodiversity in Madagascar led by Brian Fischer at California Academy of Science (CAS). Collections from the latter have field codes prefixed by BLF. Samples were collected by dissecting beetles from dead wood, or by sifting leaf litter. Types and other material examined are deposited in the following institutions: CAS - California Academy of Science, San Francisco, USA; SAMC - Iziko (South African) Museum of Cape Town, RSA; ZMHB - Museum für Naturkunde, Humboldt-Universität, Berlin, Germany; NHMW - Naturhistorisches Museum, Wien, Austria; ZUAC - Université du Antananarivo, Madagascar; ZMUB - University Museum of Bergen, Norway.

For a complete historical overview of Hypoborini classification see Alonso-Zarazaga \& Lyal (2009). Specimens were photographed using a Leica camera and LAS module and multiple photographs were aligned and stacked in ZereneStacker. Adobe Photoshop was used to crop and correct brightness. Morphological terminology follows Leschen \& Beutel (2014), with the specifications for internal characters those of Jordal (2014). Morphological characters of all body parts, both external and internal, potentially diagnostic at genus level and above were recorded. The variation in morphology was coded for phylogenetic analyses into the following character states (Table 2):

1. Eyes: (0) sinuate; (1) entire.

2. Scapus setae: (0) scattered; (1) tuft.

3. Funiculus: (0) 6-segmented; (1) 5-segmented; (2) 4-segmented: (3) 3-segmented.

4. Club sutures: (0) 2 procurved; (1) 2 recurved; (2) 2 transverse: (3) 3 transverse: (4) 1 transverse; (5) absent.

5. Club shape: (0) flat, circular; (1) flat, oval; (2) conical.

6. Pronotal shape: (0) straight; (1) dome-shaped; (2) rounded.

7. Pronotal base: (0) rounded; (1) rim.

8. Pronotal asperities: (0) anterior half; (1) few, scattered; (2) median third; (3) laterally only; (4) absent.
9. Hypomeron, setae: (0) simple; (1) bifid.

10. Interstrial rows of setae: (0) single; (1) confused.

11. Elytral base: (0) rounded; (1) rim; (2) crest; (3) doublecrested; (4) inner two teeth much longer.

12. Elytral locking system on the basal mesal flange (near scutellum): (0) toothed; (1) smooth.

13. Strial setae: (0) missing; (1) recumbent.

14. Metanepisternal setae: (0) simple; (1) bifid; (2) scales.

15. Metasternal setae: (0) simple; (1) bifid; (2) plumose/trifid.

16. Procoxae: (0) contiguous; (1) separated.

17. Protibial lateral edge: (0) curved; (1) twisted; (2) expanded.

18. Protibial inner margin: (0) straight; (1) indented.

19. Protibial lateral denticles: (0) 0 ; (1) 1 ; (2) 2 ; (3) 3 ; (4) 4; (5) 5 ; (6) 6 ; (7) 7.

20. Tarsus segment 3: (0) cylindrical; (1) heart shaped.

21. Manubrium: (0) absent; (1) shorter than tegmen thickness;

(2) longer.

22. Proventriculus, median suture: (0) absent; (1) closed; (2) open.

23. Postnotum: (0) free; (1) fused to metanotum.

24. Scutoscutellar suture: (0) parallel to scutellar groove; (1) curved, deviates from scutellar groove.

DNA sequence fragments were obtained for six genes (Table 3); mitochondrial Cytochrome Oxidase I (COI) and five nuclear gene fragments: the large ribosomal RNA gene (28S), Elongation Factor 1-alpha (EF-1a), Carbamoyl-phosphate synthetase 2, aspartate transcarbamylase, and dihydroorotase (CAD), Arginine Kinase (ArgK) and Polyadenylate-binding protein 1 (PABP1). Primers and PCR cycles were similar to those reported in Mugu et al. (2018).

Phylogenies were reconstructed in a Bayesian framework using MrBayes v. 3.2.7 (Ronquist \& Huelsenbeck, 2003). The molecular data were partitioned by codon position and gene with a GTR $+\mathrm{G}+\mathrm{I}$ for all except COI third positions that had GTR + G. Morphological data were analysed with gamma distributed character variation. The analyses ran with two parallel sets of four chains with the cold chain temperature set to 0.2. Runs were completed after the standard deviation of split frequencies reached well below 0.05 , and likelihoods obtained stationarity as inspected in Tracer (Rambaut et al., 2018). The same partitioned dataset was further tested in a maximum likelihood framework, using IQ-tree (Minh et al., 2020). The data were also optimized by maximum parsimony in PAUP* (Swofford, 2002), which assumes the simplest possible model of evolution (all rates equal) and chooses the trees with the fewest steps in character change.

Table 2. Data matrix based on morphological character states (see text for description of states).

\begin{tabular}{ll}
\hline & 000000000111111111122222 \\
& 123456789012345678901234 \\
\hline Orthotomicus proximus & 001000000000000000402100 \\
Neomicracis squamigera & 110210000000100010202200 \\
Microlanurgus bicolor & 111111010000100010100200 \\
Zygophloeus australis & $10022003013110012050 ? ? 00$ \\
Chaetophloeus heterodoxus & $10131203114111102070 ? 011$ \\
Phloeotrypetus sp. & 101512000020122010202200 \\
Cryphyophthorus eggersi & $00251214001 ? 000020402 ? ? ?$ \\
Nasiborus hylesiniformis & 102512000010122011202200 \\
Nasiborus schaufussi & 102512000010122011302200 \\
Xerasiborus quadrituberculatus & 102511000010112010302200 \\
Xerasiborus asperatus & $10151100001012201030 ? 200$ \\
Corditarsus australis & 101412020020122010212200 \\
Hypoborus ficus & 101512020020122010201100 \\
Liparthrum nigrescens & 102512020020122010202100 \\
Afrotrypetus euphorbiae & 103212021020122010202100 \\
Styracoptinus ferreirai & 113012021120122010202100 \\
Dacryostactus kolbei & $11301202112012201020 ? 100$ \\
Glochiphorus globosus & $10100200 ? 11 ? 1 ? ? 00040 ? ? 00$ \\
\hline
\end{tabular}




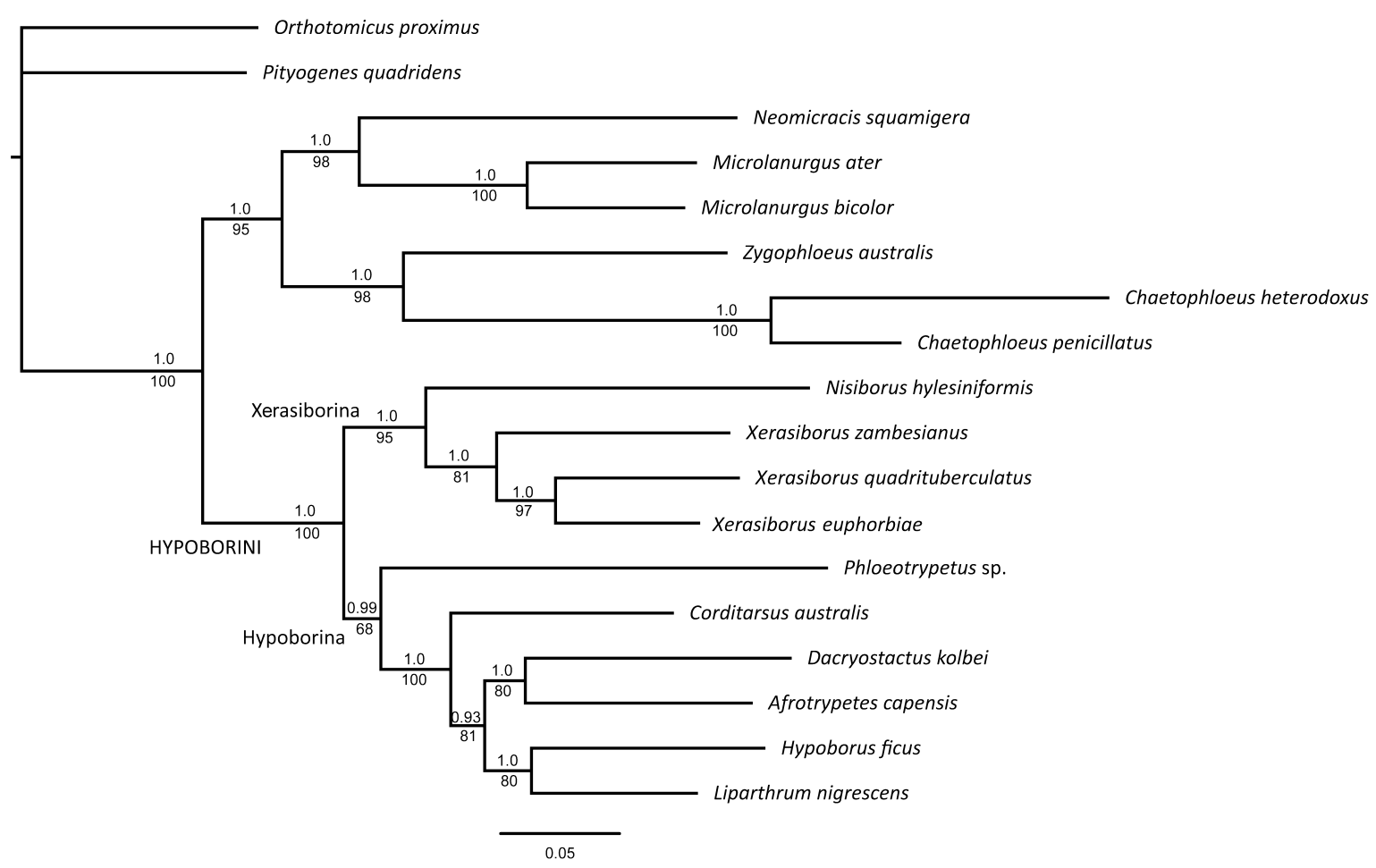

Fig. 1. Phylogeny of Hypoborini based on six gene fragments and analysed using MrBayes and IQ-tree. Node support is marked by Bayesian posterior probabilities above nodes, and ML bootstrap support values below.

Biogeographical scenarios were tested in RASP (Yu et al., 2020) using a time tree constructed from the molecular data in Beast 2.5 (Bouckaert et al., 2019). The input file for the Beast analysis was prepared in Beauti (ibid.), using the same partitions as in the Bayesian analysis. Rates were calibrated using two node dates (crown age) obtained from a recent comprehensive study of Scolytinae (Pistone et al., 2018): African Hypoborini, $41 \mathrm{Ma}$; Hypoborini including the undescribed Malagasy genus (Xerasiborus gen. n.), $64 \mathrm{Ma}$. Node ages were given a normal distribution deemed suitable for previous estimates, with a standard deviation of $5 \mathrm{Myr}$, which allows for uncertainty in past estimates.

\section{RESULTS}

\section{Phylogeny}

Bayesian searches ran for 2 million generations and converged quickly after 55,000 generations, with aver- age standard deviation of split frequencies reaching below 0.001 and an average potential scale reduction factor (PSRF) of 1.06. The tree topology was identical to the maximum likelihood topology from the IQ-tree analysis (Fig. 1). Unweighted parsimony analysis (not shown) differed in the position of the SE-Asian Phloeotrypetus, which was sister to a group of non-crested hypoborines (Xerasiborina), while in all other analyses based on more complex evolutionary models it was sister to the crested Afrotropical hypoborines.

The genus Xerasiborus gen. n., in which all species have a low carina instead of a strong crest at the elytral base, was monophyletic for its three included species, but with considerable genetic variation between them. The Malagasy species described as Ptilopodius hylesiniformis Schedl,

Table 3. GenBank sequence accession numbers for specimens included in the phylogenetic analysis. Voucher signifies the DNA extract code and the specimen extracted.

\begin{tabular}{|c|c|c|c|c|c|c|c|c|c|c|}
\hline Voucher & Tribe & Species & Country & Leg. & $\mathrm{CO} 1$ & EF-1a & $28 \mathrm{~S}$ & CAD & ArgK & PABP1 \\
\hline pOrt01 & Ipini & Orthotomicus proximu & Sweden & Jordal & $\mathrm{JX} 263835$ & JX264123 & JX263734 & 51 & $\mathrm{JX263943}$ & MF771666 \\
\hline Pit03 & Ipini & Pityogenes quadridens (Hartig, 1834) & eden & Jordal & JX263836 & JX264124 & JX263735 & - & JX263944 & $\times 160764$ \\
\hline Ecl02 & Micracidini & Microlanurgus ater Jor & car & et al & 99 & 90 & 692 & - & - & 613 \\
\hline CrCh_04 & Micracidini & Microlanurgus bicolor Jordal, 2021 & Madagascar & Fischer et al & JX263793 & JX264086 & JX263686 & - & JX2 & MF771607 \\
\hline liMio09 & Micracidini & Neomicracis squamigera Jordal, 2021 & Tan & B. Jordal & KX100011 & KY805877 & KY805985 & $\mathrm{KXO}$ & - & - \\
\hline yCha01 & Chaetophloeini & Chaetophloeus heterodoxus (Casey, 18 & USA & & & - & & 928 & & - \\
\hline $\mathrm{HyCl}$ & Chaetophlo & Chaetophloeus penicil & USA & B. J & - & $\mathrm{AF}^{3}$ & AF308371 & - & - & 657 \\
\hline 01 & Hylesinini & Zygop & & & & & 980 & KY8C & & 662 \\
\hline 01 & Hypo & Afrotr & Sol & B. & 91852 & EU191884 & JX263730 & - & - & - \\
\hline HyLip01 & Hypoborini & Cordi & $\mathrm{ca}$ & dal & 51 & EU & 354 & - & - & 60 \\
\hline $\mathrm{HyD}$ & Hyp & Dacr & Nan & S. Roth & 5902 & KY805872 & 979 & - & 52 & 58 \\
\hline Hyb01 & orini & Hуро & Made & B. Jordal & AY377006 & AY377070 & EUO & - & $\mathrm{JX} 2$ & 659 \\
\hline HyLip02 & Hypoborini & Lipar & Spain & K. Harkestad & AY377032 & AY377096 & AF308370 & - & - & 661 \\
\hline HyCry02 & Hypoborini & (Schedl, 1961) & & & 389329 & & & & & 490 \\
\hline $\mathrm{PhCla02}$ & Hypoborini & Phloeotrypetus sp. & Inc & A. & 06 & K & KY805989 & KY805021 & - & MFT \\
\hline HyGen01 & Hypoborini & Xerasiborus euphork & Madagascar & B. Jordal & MW389330 & MW387497 & 7 MW399218 & 3 MW3 & & MW387491 \\
\hline CrCh_01 & Hypoborini & Xerasiborus quadrituberculatus s & Madagasc & Fischer et al & JX263792 & JX264085 & - & JX264006 & $J X$ & MF771606 \\
\hline MiMio06 & Hypoborini & Xerasiborus zambesianus sp. $\mathrm{n}$. & Tanzania & B. Jordal & MW389331 & MW387498 & 3 MW399219 & MW387495 & & MW387492 \\
\hline
\end{tabular}




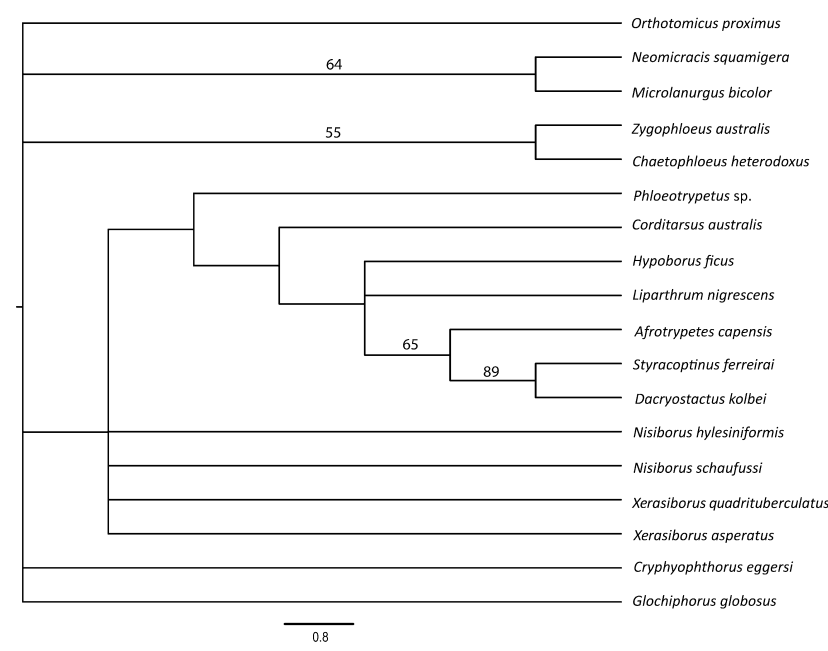

Fig. 2. Consensus tree of the 74 most parsimonious trees based on unweighted parsimony analysis of 24 morphological characters $(L=67, R I=0.69)$. Bootstrap support values below nodes.

1961 is currently placed in Cryphyophthorus, but formed the sister group to Xerasiborus and therefore is placed in a new genus Nisiborus gen. $\mathrm{n}$. The monophyly of all Afrotropical and Holarctic crested hypoborines was maximally supported as sister to Phloeotrypetus. Liparthrum australis Schedl, 1975 did not group with Liparthrum nigrescens, but formed the sister group to a clade consisting of $\mathrm{Hy}$ poborus, Liparthrum, Dacryostactus and Afrotrypetus (and Styracoptinus, see Pistone et al., 2018). To confirm its separate status, a larger data set of Liparthrum (see Jordal et al., 2004) was run for two genes (EF-1 $\alpha, \mathrm{COI}$ ) and showed the same deviant placement. This taxon is therefore placed in a new genus Corditarsus gen. $\mathrm{n}$.

Zygophloeus and Chaetophloeus did not group with Hypoborini taxa as shown in several previous phylogenetic studies (Jordal \& Cognato, 2012, Pistone et al., 2018). Parsimony analysis of morphological data resulted in a less resolved consensus tree, but with the same two taxa, and Cryphyophthorus and Glochiphorus, separate from an otherwise monophyletic Hypoborini sensu stricto (Fig. 2). It was also clear from the morphological data that Corditarsus and Phloeotrypetus deviate from other Hypoborina, and that Afrotrypetus, Styracoptinus and Dacryostactus form a strongly supported group. Bayesian analysis of the

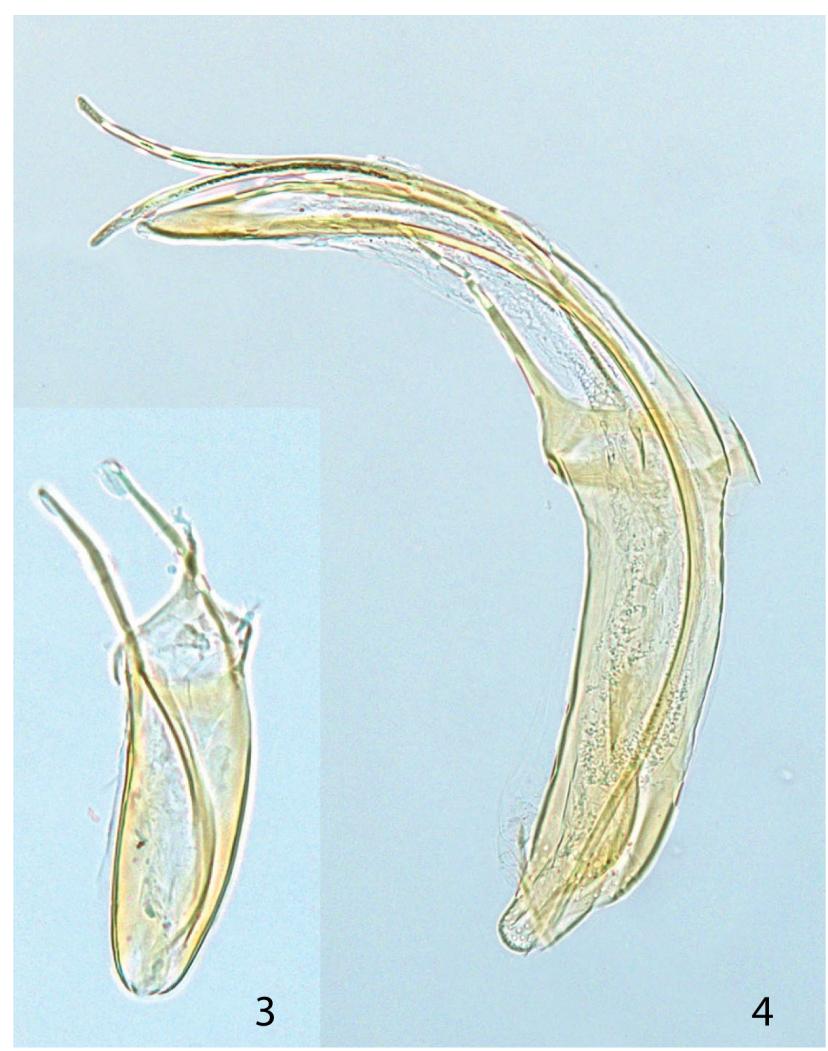

Figs 3-4. Male genitalia. 3 - Aedeagus of Xerasiborus zambesianus; 4 - aedeagus of Nisiborus schaufussi.

morphological data (not shown) supported only the latter clade, with the remaining taxa effectively forming a polytomy.

\section{Internal morphology}

Dissections of male genitalia revealed that the structure of the genitalia is very simple and varied little between the main clades (Figs 3, 4). All have a dorso-ventrally strongly curved aedeagus, with apophyses about as long as the penis, the tegmen is generally closed but not necessarily strongly sclerotised dorsally, and the spiculum gastrale is a simple rod, occasionally with a faint basal fork. Most variation involves the length of the manubrium as described for Liparthrum and Hypoborus (see Israelson, 1990).

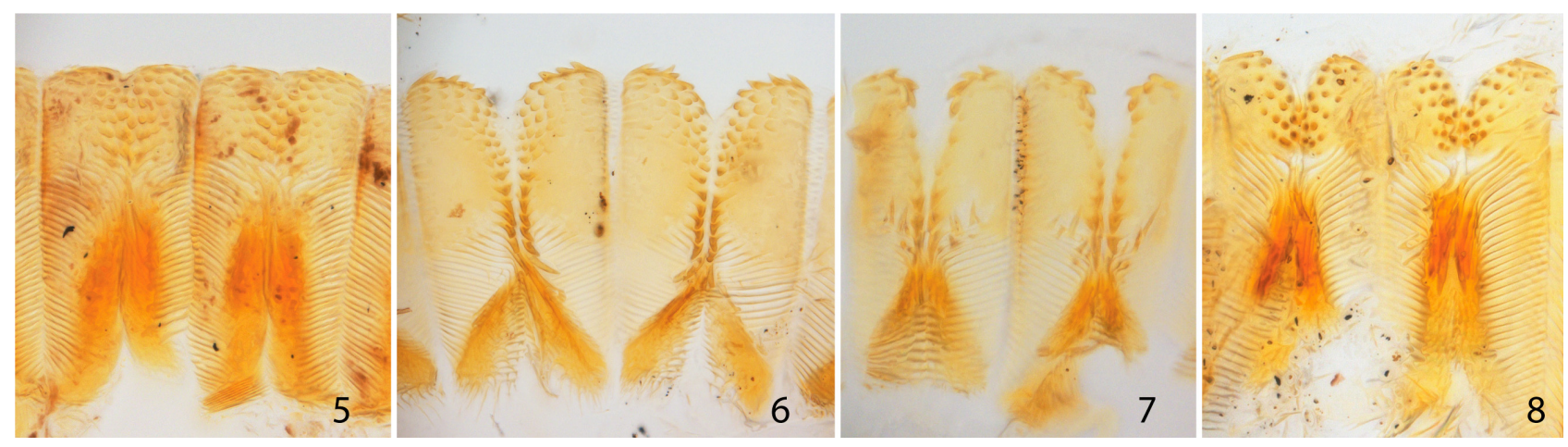

Figs 5-8. Proventriculus, inner face. 5 - Hypoborus ficus; 6 - Nisiborus hylesiniformis; 7 - Xerasiborus zambesianus; 8 - Xerasiborus quadrituberculatus. 


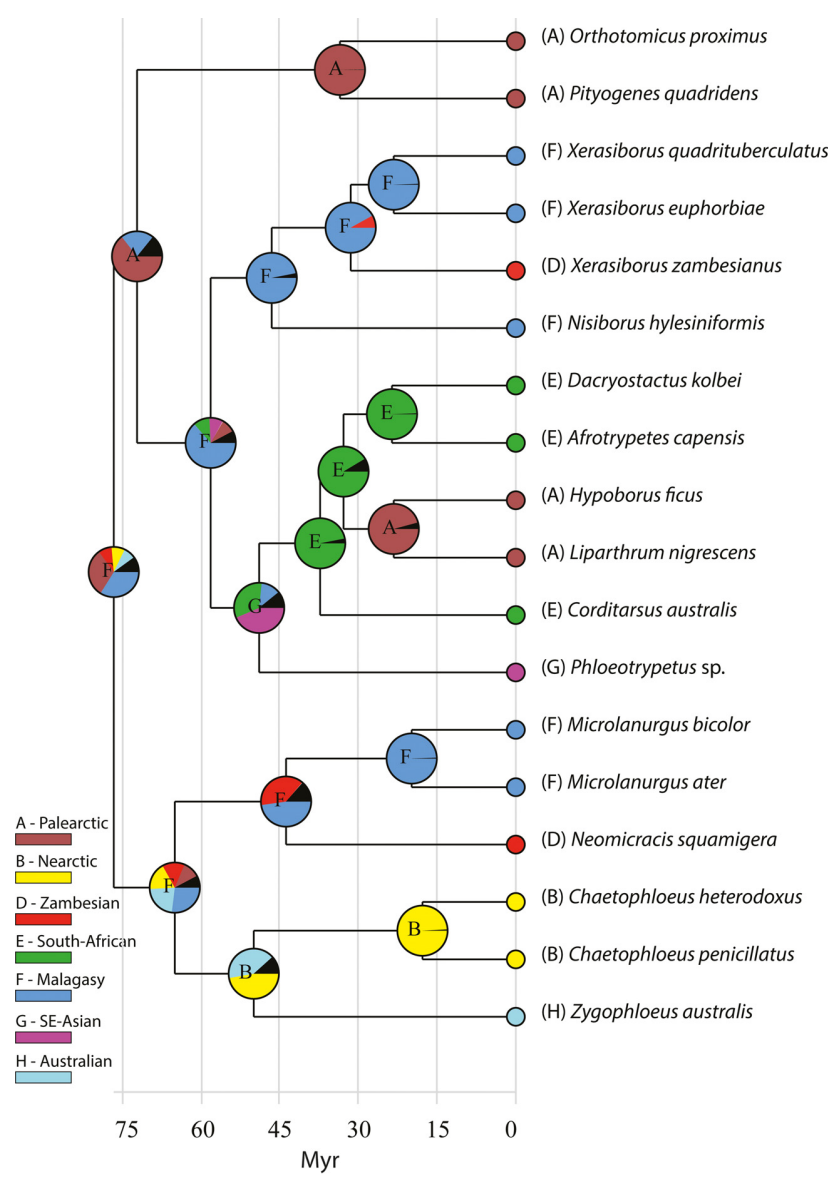

Fig. 9. Time tree resulting from the Beast analysis of molecular data, with ancestral distributions inferred in RASP using the BBM optimization. Letter in pie diagrams indicate the most likely ancestral area.

The proventriculus is also relatively simple compared to other Scolytinae (Figs 5-8). The anterior plate is longitudinally divided by a median suture, with at least irregular transverse rows of a few rounded teeth or granules. Hypoborus, Liparthrum, Styracoptinus, Dacryostactus and Afrotrypetus differ from other genera by having a closed median suture (Fig. 5). Genera in Xerasiborina subtr. n., but also Phloeotrypetus and Corditarsus, have a more open median suture (Figs 6-8).

The postnotum is separated from the metanotum and the scutoscutellar suture follows the scutellar groove for most of its length in all genera that are here included in Hypoborini. Chaetophloeus has a curved scutoscutellar suture, which quickly deviates from the groove, and the postnotum is fused to the metanotum (Israelson, 1990). Zygophloeus has a complete membrane separating the postnotum. Both genera have a toothed interlocking system on the mesal flange of the elytra near the scutellum, particularly so in Zygophloeus, while all true Hypoborini have a smooth and non-toothed flange.

\section{Biogeography}

The Beast analysis resulted in a minimum (crown) age of 58.3 Ma for Hypoborini, 48.8 Ma for Hypoborina, and 46.4 Ma for the Malagasy clade named Xerasiborina (Fig. 9). RASP analyses based on BBM optimization gave the same result as DIVA-like and DEC analyses with the jump parameter added to the biogeographical model. All these analyses inferred vicariance in conjunction with dispersal. Ancestral distributions during the Palaeocene were ambiguously inferred. Several younger events were strongly supported, including a single colonization of Madagascar in the mid-Eocene or earlier, with recolonization of the African mainland known only from a single event in the Oligocene. The Eocene was also the time of origin of African hypoborines, with a more recent radiation occurring northwards into the Mediterranean and Macaronesian region no later than the onset of the Miocene.

\section{TAXONOMY}

\section{Tribus Hypoborini Nüsslin, 1911}

Type genus. Hypoborus Erichson, 1836.

Diagnosis. Eyes entire, oval to elongated. Scapus elongated, much longer than funiculus, funiculus 3-5 segmented, club flattened, smooth and glabrous to largely pubescent, often with weakly marked sutures. Pronotum granulated or asperate on at least the anterior half, often with larger asperities on median third; pronotal vestiture consisting of mixed hair-like and scale-like setae; scutellum not clearly visible from above. Elytral base at least with a small irregular rim, more often with crenulations near scutellum; interstrial setae usually scale-like, mainly in single rows, strial setae fine, recumbent, rarely a dense ground vestiture consisting of short scales. Procoxa contiguous; mesocoxae broadly separated. Protibiae narrow, with 1-4 socketed teeth on their lateral and apical margins, the inner mucro rather long, curved posterolaterally; mesoand metatibiae narrow, with 2-5 fine, socketed, lateral teeth on apical one-third or less. Setae on metanepisternum scale-like or plumose, running in a parallel with the sclerolepidia, posteriorly turning dorsally on the epimeron and usually also ventrally just anterior to the metacoxa. Hindwings with clusters of 1,3 or 5 setae on the subcosta, 2 or 3 on radial cell (pterostigma). Postnotum separated from metanotum by a membrane. Scutoscutellar suture straight, parallel with the scutellar groove. Proventriculus with median longitudinal suture on the anterior plate, suture closed or wide open, tubercles rounded, in irregular rows, sometimes large sutural teeth present. Male genitalia dorsoventrally strongly curved, apophyses about as long as penis, tegmen closed, occasionally weakly sclerotized dorsally, manubrium distinct, often long and curved like apophyses, spiculum gastrale a simple rod.

Included genera: Afrotrypetus Bright, 1981 stat. res., Corditarsus gen. n., Dacryostactus Schaufuss, 1905, Glochiphorus Strohmeyer, 1910, Hypoborus Erichson, 1836, Liparthrum Wollaston, 1854, Nisiborus gen. n., Phloeotrypetus Wood, 1960, Styracoptinus Wood, 1962, Trypanophellos Bright, 1982, Xerasiborus gen. n.

Excluded genera: Chaetophloeus LeConte, 1858, Cryphyophthorus Schedl, 1953, Zygophloeus Schedl, 1958.

Remarks. Species of Hypoborini are morphologically similar to, but phylogenetically very distant from, Micracidini. They share features of their protibiae and digestive 

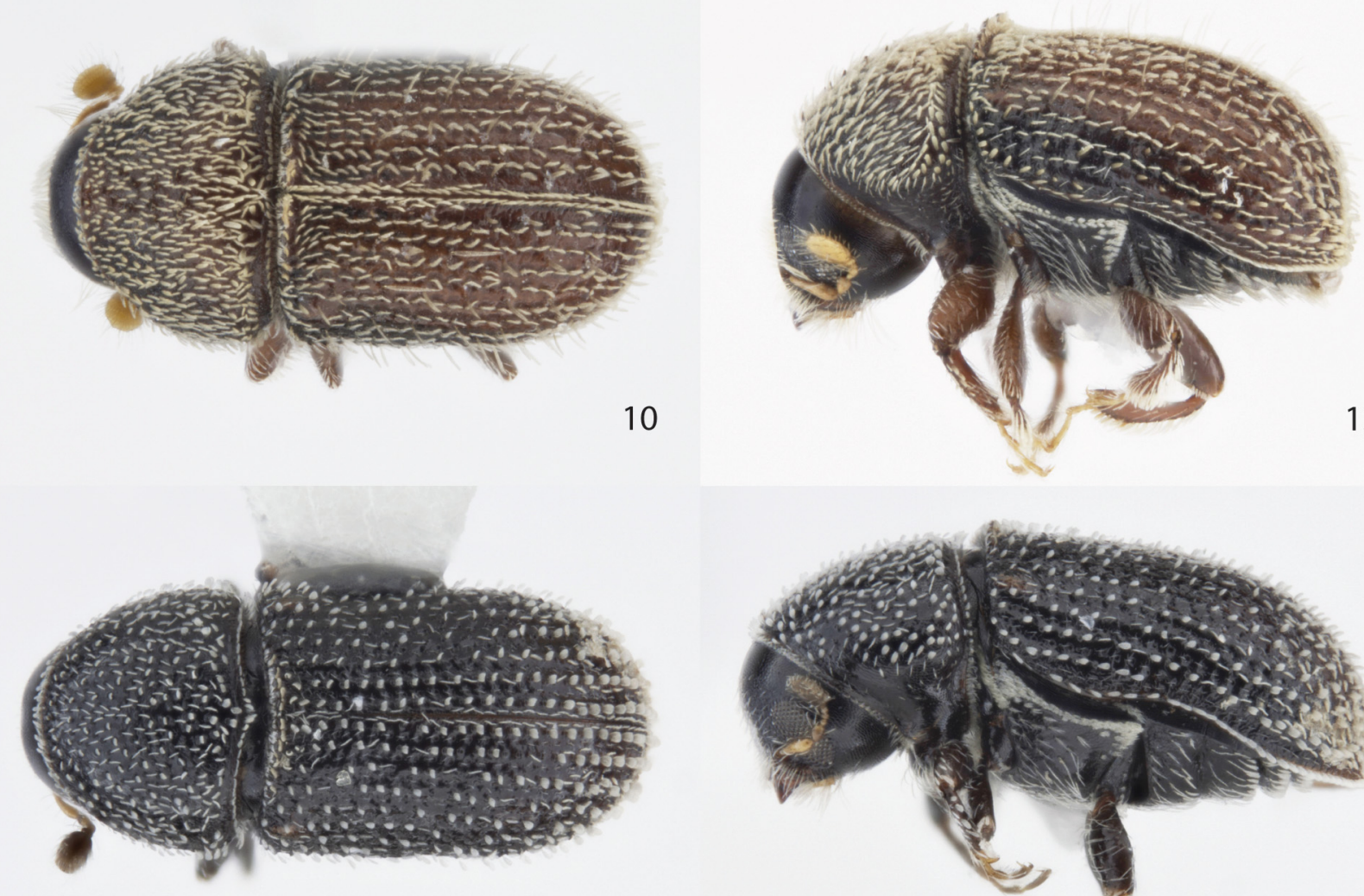

11

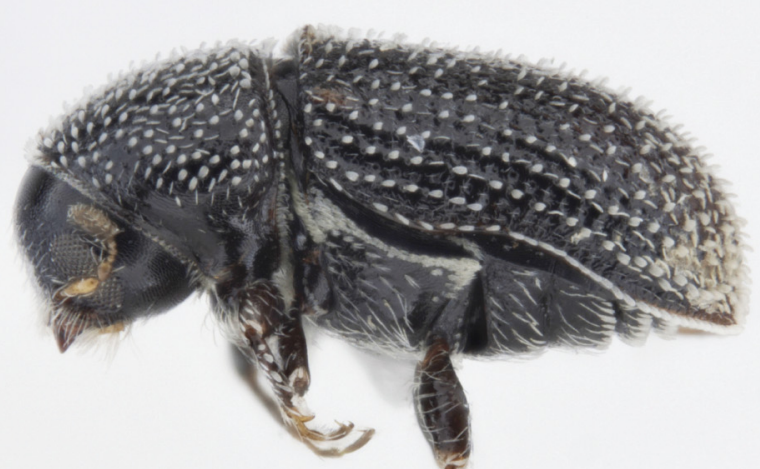

14
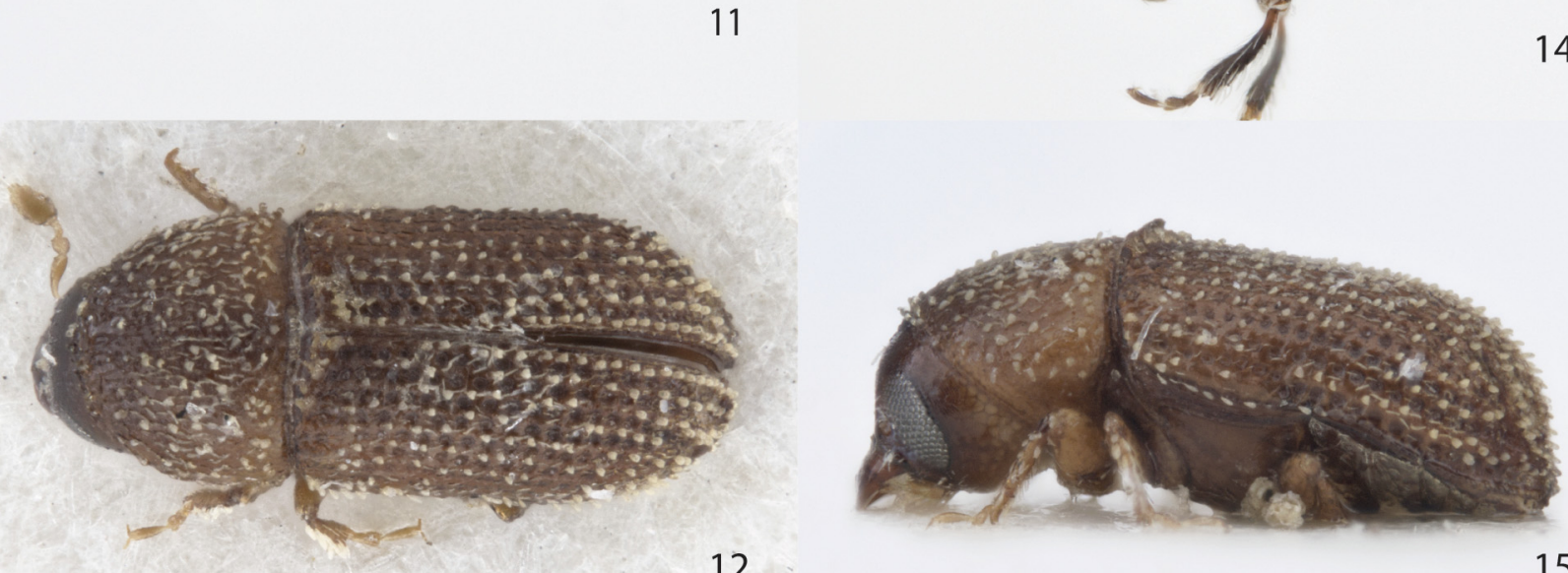

15
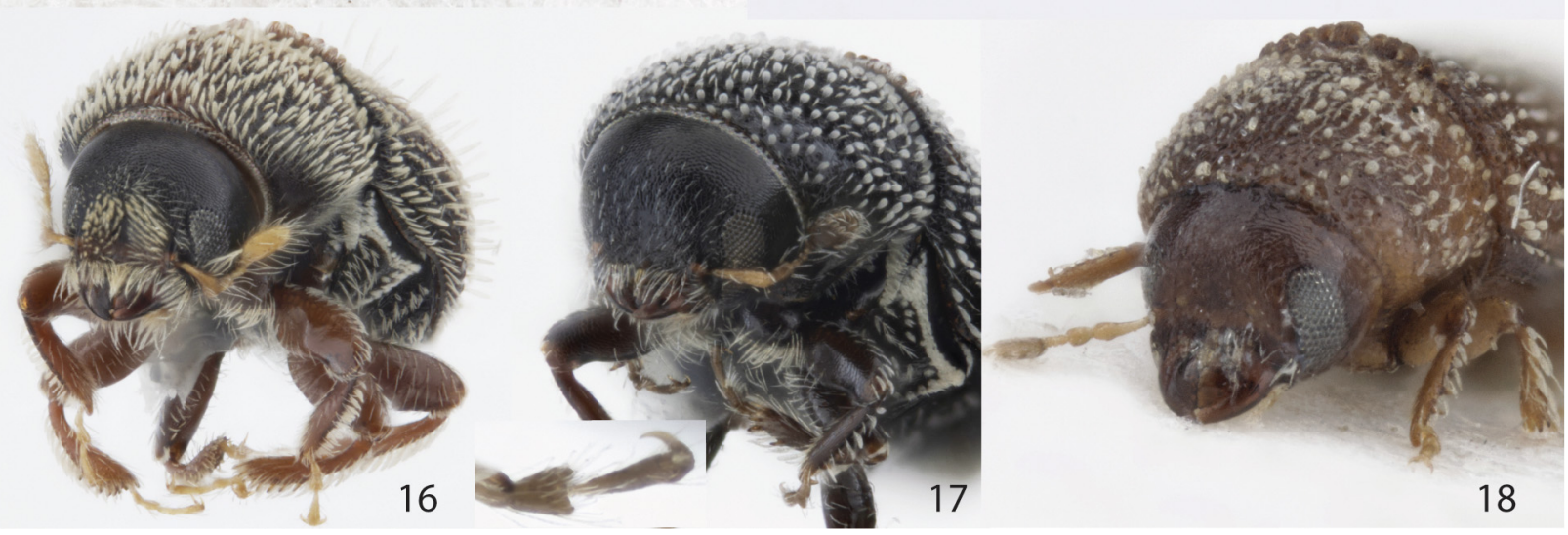

Figs 10-18. Dorsal, lateral and front view of Hypoborus and Corditarsus. 10, 13, 16 - Hypoborus ficus; 11, 14, 17 - Corditarsus australis; $12,15,18$ - Corditarsus tanganyikaensis, holotype. 
system (mouthparts and proventriculus), especially with the Afrotropical members of that tribe. They can nevertheless be readily distinguished by the pattern of setae on the metanepisternum, hidden scutellum and elevated base of elytra. Previous phylogenetic analyses indicate a Cretaceous age for Micracidini and possibly Hypoborini (Pistone et al., 2018), which may explain the limited phylogenetic resolution with respect to putatively close relatives.

Three genera are here excluded from Hypoborini. Another genus, Glochiphorus, was not investigated in sufficient detail given the limited material available (no dissections) and therefore only tentatively included in the tribe (see below).

\section{Key to the Afrotropical genera of Hypoborini}

1 Elytral base finely carinated (Fig. 42) or with a crest of a single row of raised teeth (Fig. 15); eyes entire; basal pronotal margin round; setae on metanepisternum usually plumose or scale-like, in a single horizontal row parallel to sclerolepidia, posteriorly turning dorsally on the metepimeron and ventrally just anterior to the metacoxae (Fig. 13) (Hypoborini)........... 2

- Elytral base rounded and metanepisternal setae not in rows, or if crested the base consists of multiple rows of teeth, or the eyes are sinuate, emarginate or divided, or base of pronotum forms a sharp rim (Fig. 50); setae on metanepisternum either absent, or unifid, or if plumose not in a row parallel to sclerolepidia. not Hypoborini

2 Elytral base has a sharp rim; pronotal asperities nearly reach lateral margins, equally sized except on anterior margin (Figs 33,48 ); hindwing subcosta with either 1 or 5 setae in a cluster (Xerasiborina subtr. n.) ....................................................... 3

- Elytral base has a marked crest with 4-8 vertical teeth between interstriae 1-4; pronotal asperities mainly on median third, larger than lateral asperities (Figs 19, 21); hindwing subcosta with a cluster of 3 long setae (Hypoborina)........... 5

3 Antennal club elongate, smooth and shiny, sutures only indicated by setae on lateral margins (Figs 44, 54); funicular segment 1 (pedicel) longer than other segments ................... 4

- Antennal club broad and round, with two broadly procurved sutures marked by setae; funicular segment 2 longer than other funicular segments (Madagascar, South Africa?).

Glochiphorus

4 Pronotum longer than wide, asperities small and granule-like (Fig. 51); antennal club with scattered long lateral setae (Fig. 54) (Madagascar) ........................................ Nisiborus gen. n.

- Pronotum wider than long, asperities usually very large, rounded thorns (Figs 31,33); club with lateral tufts of short setae (Fig. 44) (Madagascar, Tanzania) ... Xerasiborus gen. n.

5 Antennal funiculus 3-segmented, club with transverse (Fig. 24) or procurved (Fig. 30) sutures strongly marked (if weakly marked, club elongated and pilose); setae on lateral edge of pronotum bifid (Fig. 29) ...

Antennal funiculus 4 - or 5 -segmented; chub with var number of transverse sutures; setae on lateral margin of pronotum simple (Figs 13, 14)...

6 At least some interstriae with many confused rows of ered setae; interstriae 2 with a row of large spines or tubercles (Figs 25, 26); antennal club with two strongly procurved sutures, antennal scapus with a narrow tuft of long setae (Figs 29,30 ); plumose setae on metanepisternum and near metacoxae.
- Setae on all interstriae in single rows; elytral tubercles absent (Fig. 19); antennal club with transverse sutures lightly indented and marked by setae (Fig. 23), scapus with scant, short setae; metanepisternum largely glabrous, with plumose setae only present near metacoxae (Figs 21, 22) (South Africa, Namibia) Afrotrypetus

7 Eyes and antennal clubs very elongated, $>3 \times$ longer than wide; largest elytral tubercle located on anterior fifth (South Africa, Namibia, Angola) ............................... Dacryostactus

- Eyes and antennal club less than $2 \times$ longer than wide; largest elytral tubercles located on posterior half (Mozambique to Angola and South Africa) ................................. Styracoptinus

8 Elytra with very long, scattered, bristle-like setae mainly on odd-numbered interstriae (Fig. 10); antennal funiculus 5-segmented, last funicular segment at least $2 \times$ broader than segment 4 (Holarctic, Madagascar?)............................Hypoborus Elytral interstriae with short spatulate scale-like setae (a few Liparthrum with hair-like setae); antennal funiculus 4- or 5 -segmented, last segment at most $1.5 \times$ broader than segments $2-4$.

9 Antennal funiculus 5-segmented; club with one fine transverse suture; asperities on pronotum small, of similar size; lateral edge of pro-and mesotibiae with broad, scale-like setae (Figs 17, 18); third tarsal segment heart-shaped, usually much broader than tarsal segment 2; abdominal ventrites III-V with additional small, round, scale-like setae; anterior plate of proventriculus divided, suture broad (South Africa) ...............

. Corditarsus gen. $\mathrm{n}$.

- Antennal funiculus 4-segmented; club with variable number of sutures; asperities on median half of pronotum larger than on lateral areas; lateral edge of pro-and mesotibiae with fine or coarse but not scale-like setae; third tarsal segment almost cylindrical, not much broader than segment 2; all abdominal ventrites with hair- and bristle-like setae; anterior plate of proventriculus with closed median suture (Mediterranean area, Atlantic islands south to Cape Verde, Neotropics, Pacific, SE-Asia) Liparthrum

\section{Subtribus Hypoborina Nüsslin, 1912}

Type genus. Hypoborus Erichson, 1836.

Diagnosis. Pronotal asperities larger on median third of anterior half, only small granules present on lateral areas. Elytral base with crest of 5-9 vertical teeth between scutellum and interstriae 4. Hindwings with a cluster of 3 setae on subcosta. Proventriculus usually with closed median suture on anterior plate, occasionally narrowly open.

Included genera: Afrotrypetus Bright, 1981 stat. res., Corditarsus Jordal, gen. n., Dacryostactus Schaufuss, 1905, Hypoborus Erichson, 1836, Liparthrum Wollaston, 1854, Phloeotrypetus Wood, 1960, Styracoptinus Wood, 1962, Trypanophellos Bright, 1982.

Remarks. This subtribe includes the majority of taxa originally placed in this tribe, except Chaetophloeus, which is radically different not only in internal characters but also in several external features such as the protibia and antennal club. The primary defining feature of Hypoborina is the basal elytral crest of equally long vertical teeth between interstriae 1 and 4.

\section{Genus Hypoborus Erichson, 1836}

Figs 10, 13, 16

Type species. Hypoborus ficus Erichson, 1836 (monotypic). 


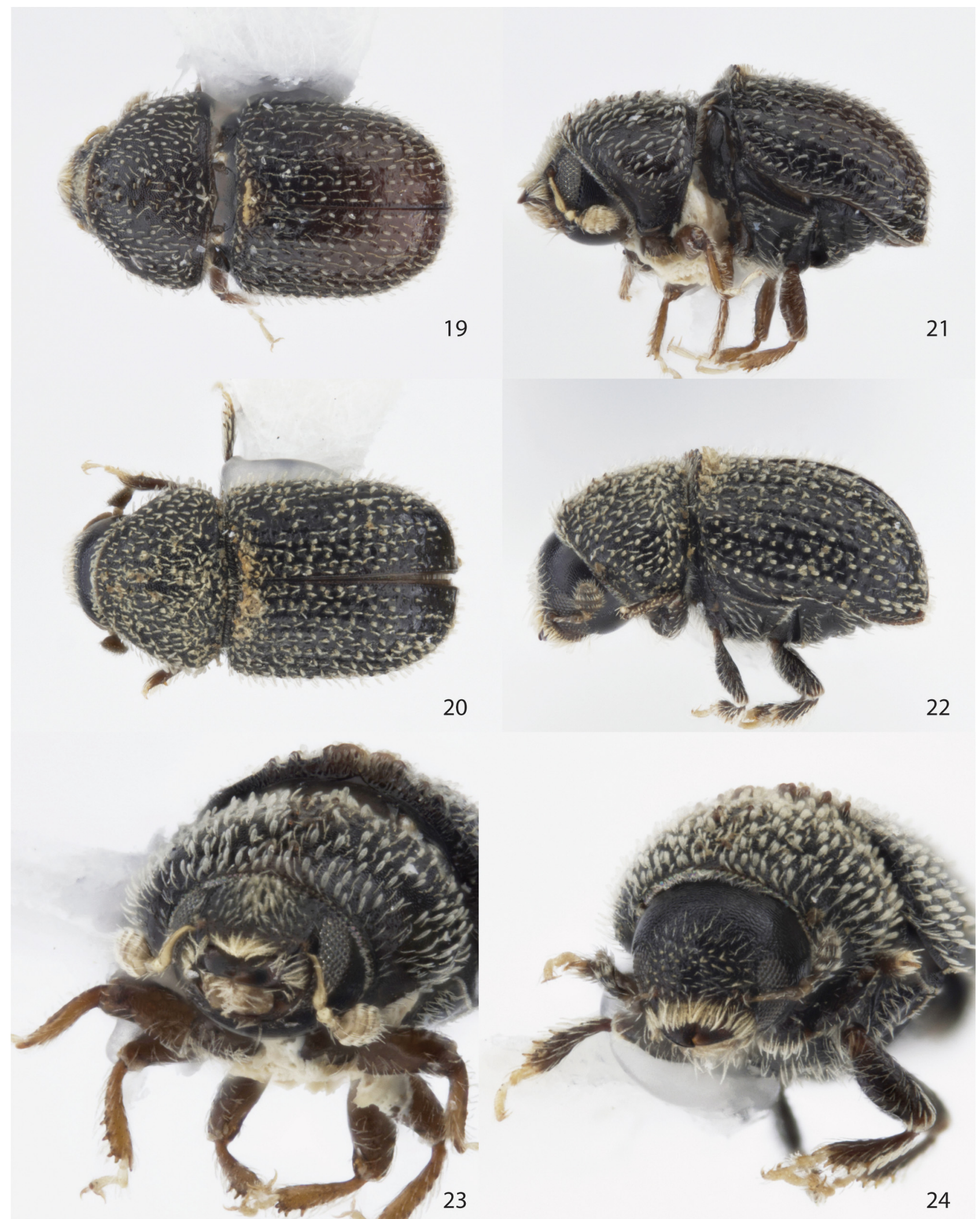

Figs 19-24. Dorsal, lateral and front view of Afrotrypetus spp. 19, 21, 23 - Afrotrypetus euphorbiae; 20, 22, 24 - Afrotrypetus capensis, holotype.

Diagnosis. Antennal funiculus 5-segmented, last segment laterally strongly extended; club with three barely visible transverse sutures marked by scattered setae. Base of elytra with all teeth equally separated; vestiture consisting of irregular strial rows of recumbent, bristle-like setae, and much longer, erect, bristle-like interstrial setae, mainly on odd-numbered interstriae. Pro- and mesotibiae with fine to coarse hair-like setae.

Included species: Hypoborus ficus Erichson, 1836. 
Excluded species: Hypoborus tanganyikaensis Schedl, 1972 (to Corditarsus gen. n.).

Distribution. North America, Europe, Atlantic islands, North Africa, Madagascar?

Remarks. Specimens of $H$. ficus are reported from Madagascar but not confirmed (Schedl, 1977). This species is thought to be invasive (Haack, 2001) and is widespread in warm temperate and arid subtropical climates, feeding on dead Ficus branches (Israelson, 1990). Another species described in this genus, $H$. tanganyikaensis, differs in that funicular segment 5 is less extended laterally, all interstrial setae are short and scale-like, and the setae along the lateral edges of the tibia scale-like, and is therefore transferred to Corditarsus gen. $\mathrm{n}$.

\section{Genus Liparthrum Wollaston, 1854}

Type species. Liparthrum bituberculatum Wollaston, 1854 (original designation).

Diagnosis. Antennal funiculus 4-segmented, last segment slightly wider than other segments; club variable, often smooth, sometimes with one or two faint sutures marked by scattered setae. Base of elytra with raised teeth variably spaced; vestiture consisting of regular strial rows of recumbent, fine setae, and longer erect scale-like or bristle-like interstrial setae in rows, occasionally with multiple confused rows of bristle-like setae. Pro- and mesotibiae with fine to coarse hair-like setae.

Included species: 36 species, but none present in the Afrotropical realm.

Excluded species: Liparthrum australis Schedl, 1975 (to Corditarsus); Liparthrum palauensis (Wood, 1960) (to Phloeotrypetus).

Distribution. North America, Pacific islands, SE-Asia, Southern Europe, Mediterranean area, Caucasus, Macaronesian islands. This genus is particularly species-rich on subtropical Atlantic islands (Jordal, 2006).

Remarks. All Macaronesian and Mediterranean species form a monophyletic group, which includes the type species of Liparthrum (Jordal et al., 2004). Some undescribed species in SE-Asia are similar to Liparthrum palauensis (Wood, 1960), a species originally described in the genus Phloeotrypetus Wood, which is currently placed as a synonym in Liparthrum (Wood \& Bright, 1992) but restored here (see below). Molecular data (Fig. 1) and the structure of the proventriculus strongly indicate that this particular lineage is not part of Liparthrum and that a taxonomic revision of the SE-Asian and North American species, including Trypanophellos, is required.

\section{Genus Corditarsus gen. n.}

Figs 11, 12, 14, 15, 17, 18

ZooBank taxon LSID:

\section{C80B6-2043-4865-8CD5-A536CE3EAEC8}

Type species. Liparthrum australis Schedl, 1975.

Diagnosis. Eyes short, entire. Antennal club generally smooth and shiny, with one transverse, fine suture on anterior third marked by very fine, short setae. Funiculus 5-seg- mented, last segment about $1.5 \times$ broader than segments 2-4. Pronotum typical of Hypoborina with large asperities restricted to median third on anterior three-quarters. Third tarsal segment heart-shaped, twice as broad as tarsal segment 2 (less so in C. tanganyikaensis). Abdominal ventrites 2-5 each with a transverse row of dense scale-like setae along the posterior margin, in addition to irregular hair-like setae. Pro- and mesotibiae with long, curved, scale-like setae along lateral edges.

Etymology. Latin, combining the genitive form cordis of the noun cor, meaning heart, and the noun tarsus (foot), referring to the broad and heart-shaped third tarsal segment. Gender masculine.

Included species: Corditarsus australis (Schedl, 1975) comb. n., Corditarsus tanganyikaensis (Schedl, 1972) comb. n.

Distribution. Known from South Africa and Tanzania.

New records. Corditarsus australis: South Africa, Western Cape, Gouna, near Knysna [-33.946, 23.054], ex Virgilia oroboides, 6. Nov. 2006, B. Jordal leg; Western Cape, Nature's Valley [-33.965, 23.562], ex Virgilia divaricata, 8. Nov. 2006, B. Jordal leg. (20 specimens in ZMUB, 5 specimens in SAMC).

Remarks. Molecular data support a position of C. australis separate from other Liparthrum and Hypoborus. This species also differs in that the median suture on proventriculus is open, the antennal club has a single transverse suture and there are intermixed scale-like setae on the abdominal ventrites. The peculiar heart-shaped third tarsal segment and broad scale-like setae along the lateral edge of the tibiae are unique features in Hypoborini.

Host plant. C. australis is recorded for the first time from Virgilia (Fabaceae) in which it makes small cave-like egg-tunnels. The male leaves the nest early while females were found alone with young broods. This species was previously collected from another genus of Fabaceae, Lonchocarpus, in the Kruger National Park (Schedl, 1975).

\section{Key to species}

1 Mandibles normal; frons weakly impressed just above epistoma; tarsal segment 3 at least twice as broad as segment $2 \ldots .$. ..Corditarsus australis

- Mandibles enlarged, almost prognathous; frons distinctly concave with margins rounded; tarsal segment 3 about $1.5 \times$ broader than segment 2 .Corditarsus tanganyikaensis

\section{Genus Afrotrypetus Bright, 1981 stat. rev.}

Figs 19, 21, 23

Type species. Afrotrypetus euphorbiae Bright, 1981 (original designation).

Diagnosis. Antennal scapus with scant setae, funiculus 3-segmented, club with two distinct, transverse, sutures. Pronotum with simple setae, some bifid setae near hypomeron. Elytral base with first two teeth on each elytron (near scutellum) fused and an additional three teeth.

Included species: Afrotrypetus euphorbiae Bright, 1981, Afrotrypetus capensis Jordal, sp. n.

Distribution. South Africa, Angola. 


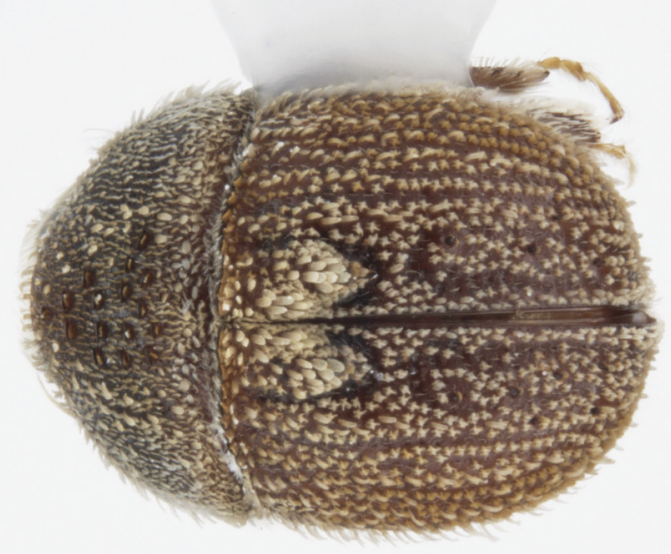

25
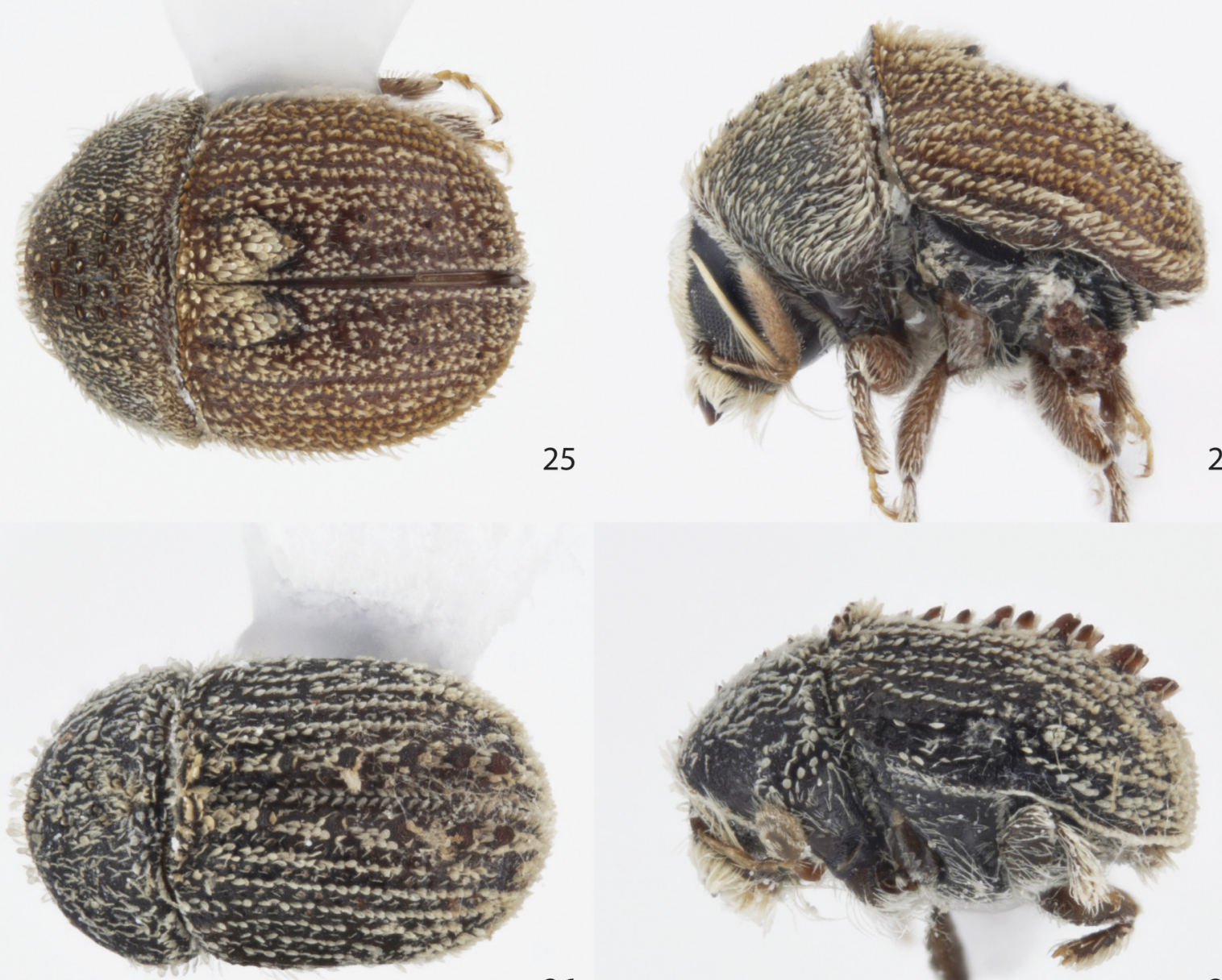

26
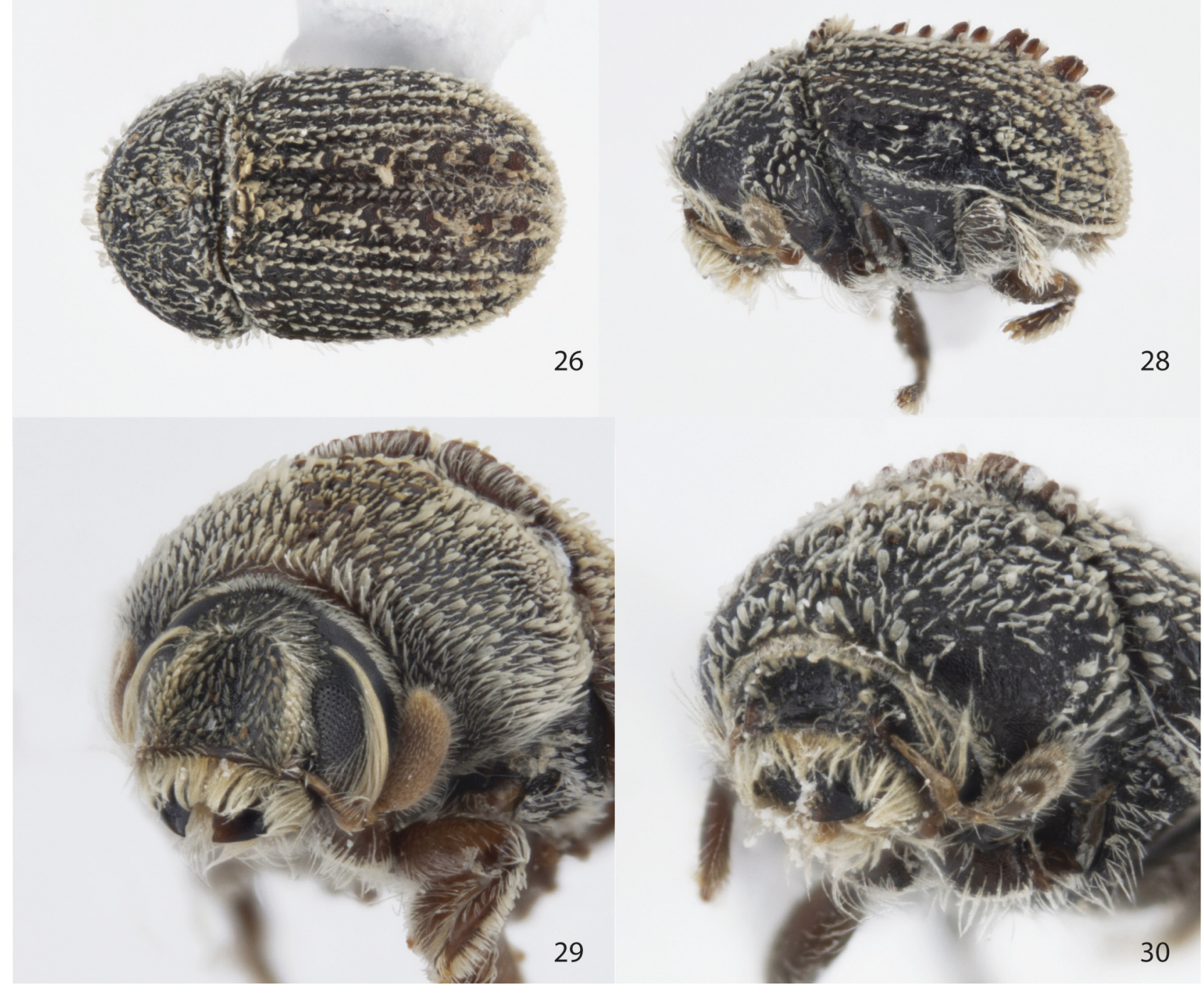

Figs 25-30. Dorsal, lateral and front view of Dacryostactus and Styracoptinus. 25, 27, 29 - Dacryostactus kolbei; 26, 28, 30 - Styracoptinus ferreirai.

New records. Afrotrypetus euphorbiae: Angola, Namibe province, $10 \mathrm{~km}$ S Namibe, -15.593, 12.198, 8.iii.2015, ex Euphorbia sp., S. Roth, leg. (one specimen, ZMUB).
Remarks. Wood (1983) erroneously synonymized Afrotrypetus with Styracoptinus, arguing that $A$. euphorbiae intergrades with the three known species of the latter genus. 
This is not the case. All three Styracoptinus species have antennal clubs with two procurved sutures and a long tuft of fine setae on the scapus. In addition, they have tubercles and spines on the elytra, which are absent in Afrotrypetus.

\section{Key to species}

1 Interstrial setae spatulate or pointed, about $2-3 \times$ as long as wide; strial setae bristle-like (Angola, South Africa) .............. . Afrotrypetus euphorbiae

- Interstrial setae truncated, as wide as long; strial setae fine and hair-like (South Africa)........ Afrotrypetus capensis sp. n.

\section{Afrotrypetus capensis sp. $\mathbf{n}$.}

Figs 20, 22, 24

ZooBank taxon LSID:

EE576FD8-B456-45CA-B3F8-7519AA302E82

Diagnosis. Antennal funiculus 3-segmented, club with two transverse sutures. Plumose setae sparse on median three quarters of metanepisternum. Interstrial setae truncated, as broad as long, strial setae coarse.

Description male. Length $1.0-1.1 \mathrm{~mm}, 2.0 \times$ as long as wide. Colour black. Head. Frons convex, strongly reticulate, slightly impressed and shiny on median third just above epistoma; vestiture consisting of fine hair-like setae and fewer spatulate setae directed inwards, a dense brush on epistoma. Scapus long; funiculus 3-segmented, pedicel longer than segments 2-3 combined; club with two transverse sutures marked by setae and small grooves. Pronotum strongly reticulate, granulated and sharply asperate on median third of anterior three-quarters, two small asperities near anterior margin; vestiture of mixed recumbent fine setae and erect scale-like setae, some fine bifid setae near lateral margin. Scutellum not visible. Elytral base with raised crest consisting of five equally long teeth on each elytron, the inner two on each elytron fused; striae weakly impressed, punctures deep, in regular rows, separated within rows by half their diameter; interstriae and space between strial punctures rugose. Vestiture consisting of erect, truncated interstrial setae, and coarse recumbent strial setae spaced their length apart. Legs. Protibiae laterally with 2 tiny teeth, inner mucro long and curved posterolaterally. Meso- and metatibiae with 4 lateral socketed teeth on apical third.

Female. Identical to male.

Type material. Holotype, male: South Africa, East Cape, Ecca Pass, N. Grahamstown [-33.196, 26.168], ex. Euphorbia triangularis (\#1) 16 Nov. 2006, B. Jordal, leg. Paratypes: same data as holotype (2). Holotype and one paratype in SAMC, one paratype in ZMUB.

Additional material. South Africa, Namaqualand, Leliefontein, $1048 \mathrm{~m},-30.39,18.28$, Malaise trap, 27.ix.2003, leg. Carolin Mayer (2 specimens, ZMHB).

Type locality. South Africa, East Cape province, Ecca Pass.

Etymology. Named after the Cape region in South Africa.

Distribution. Known from the Eastern Cape and North Cape provinces of South Africa.

Remarks. Breeds in dead parts of large succulent Euphorbia. Differs from the very similar $A$. euphorbiae by the short and broad truncated interstrial setae, which are more densely spaced, and by the thicker strial setae. There are also slight differences between the two species in the shape and distribution of the coarse and fine setae on the pronotum.

\section{Genus Dacryostactus Schaufuss, 1905}

Figs 25, 27, 29

Type species. Dacryostactus kolbei Schaufuss, 1905 (monotypic).

Diagnosis. Antennal scapus with a long tuft of setae on distal third; funiculus 3-segmented; club strongly elongated, pubescent, with two procurved sutures barely visible. Pronotum with some bifid setae intermixed near lateral margin. Elytral base with crenulation reaching interstriae 6, with first two teeth on each elytron fused, additional 4-5 teeth free; elytral interstriae 2 with sharp spines, which are slightly longer than elytral setae.

Distribution: Angola, Namibia, South Africa

New record. Dacryostactus kolbei: Angola, Namibe province, Serra da Neva, -13.144, 13.132, 17.iii.2015, S. Roth, leg. (two specimens in ZMUB).

Remarks. Even though this characteristic species differs markedly in several features from Styracoptinus, it is not unlikely that they are congeneric given the modest genetic differences observed in many genes (Pistone et al., 2018).

\section{Genus Styracoptinus Wood, 1962}

Type species. Styracopterus murex Blandford, 1896 (monotypic).

Diagnosis. Antennal scapus with a long tuft of setae on distal third; funiculus 3-segmented; club with two strongly procurved sutures marked by setae. Pronotum with some bifid setae intermixed laterally along the hypomeron. Elytral base with first two teeth on each elytron fused and an additional three teeth; elytral disk and declivity with spines and tubercles.

Included species: Styracoptinus murex (Blandford, 1896), Styracoptinus cavipennis (Schedl, 1969), Styracoptinus ferreirai (Schedl, 1969) (Figs 26, 28, 30).

Excluded species: Styracoptinus euphorbiae (Bright, 1981) (to Afrotrypetus).

Distribution. Africa (southern countries).

New records. Styracoptinus ferreirai: Angola, Namibe province, Serra da Neva, $-13.144,13.132$, 17.iii.2015, S. Roth, leg. (new country) (five specimens in ZMUB).

Remarks. Species vary slightly intraspecifically in the ornamentation on the elytra and there may be some semicryptic diversity.

\section{Key to species}

1 Elytral disk without spines, declivity with a series of spines around its margin (Mozambique) ... Styracoptinus cavipennis

- Elytral disk and declivity with spines and tubercles............. 2

2 Interstriae 2 with a series of thick tubercles (Mozambique, Angola) ............................................. Styracoptinus ferreirai

- Interstriae 2 and 5 with sharp, long spines (Southern countries of Africa)..................................................Styracoptinus murex 


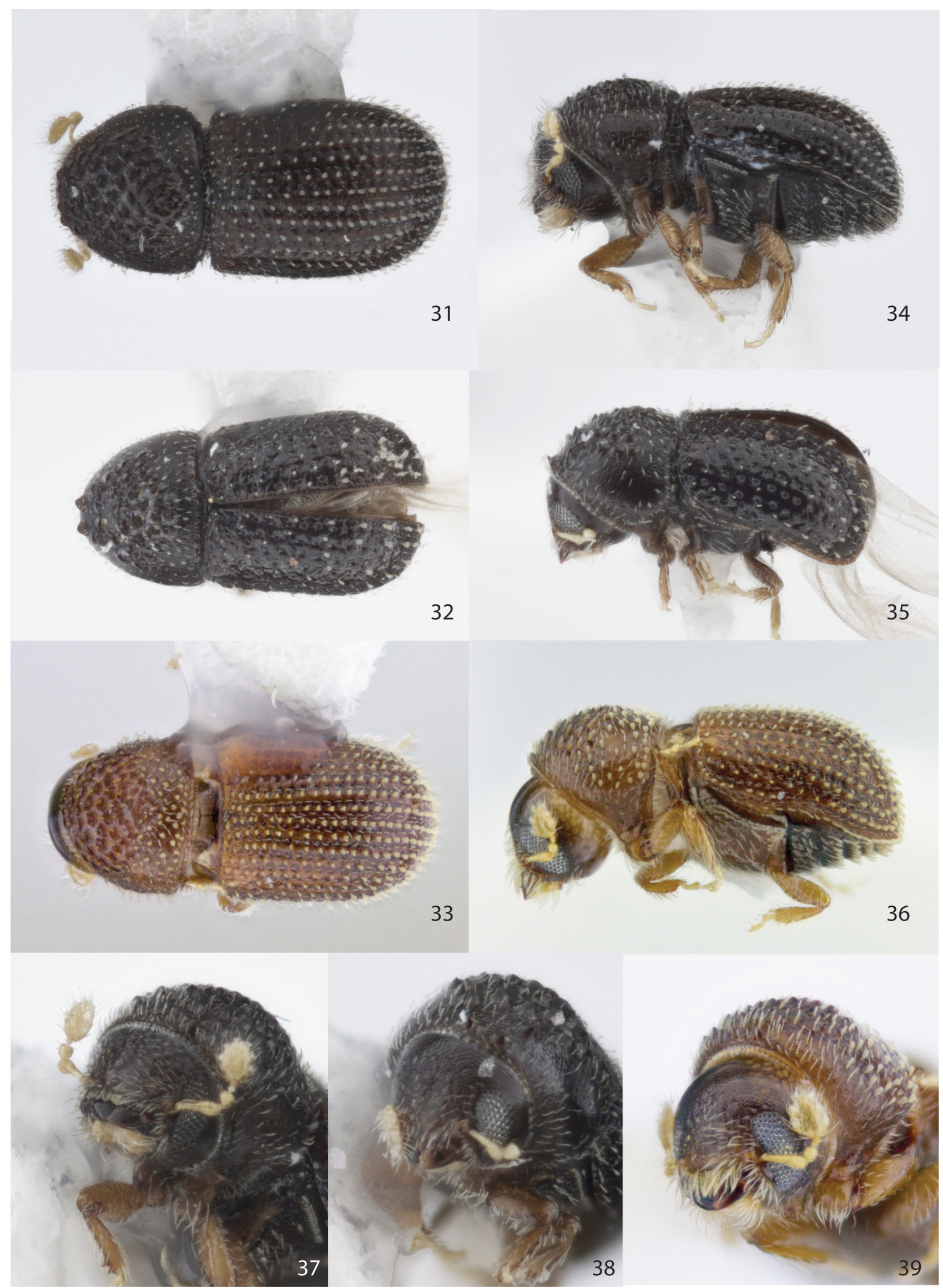

Figs 31-39. Dorsal, lateral and front view of Xerasiborus holotypes. 31, 34, 37 - Xerasiborus quadrituberculatus; 32, 35, 38 - Xerasiborus bituberculatus; 33, 36, 39 -Xerasiborus zambesianus. 


\section{Subtribus Xerasiborina subtrib. $\mathbf{n}$.}

ZooBank taxon LSID: 68D52DC7-CC6F-4C19-9BDA-3F499619603D

Type genus. Xerasiborus gen. $\mathrm{n}$.

Diagnosis. Eyes entire, short. Antennal club smooth and glabrous without marked sutures but with lateral tufts of setae. Pronotum granulated or asperate on anterior half, nearly reaching lateral margins. Elytral base with a low irregular rim. Hindwings with 1 or 5 setae on subcosta. Proventriculus with anterior plate divided, median suture open, diverging anteriorly.

Included genera: Nisiborus gen. n., Xerasiborus gen. n., Glochiphorus Strohmeyer, 1910.

Remarks. Molecular data, morphological features of male genitalia and external characters such as a contiguous row of plumose setae on most of the metanepisternum, short entire eyes, and the shape of the protibiae, support a close relationship with Hypoborina and thereby inclusion in Hypoborini. The phylogenetic position as sister to Hypoborina, the lack of raised teeth along the elytral base, and, although not exclusively, the open anterior plate on the proventriculus, support a separate status as a subtribe in the Hypoborini.

\section{Genus Xerasiborus gen. $\mathbf{n}$.}

ZooBank taxon LSID:

F2D6C40F-CF3C-4CDD-A2CE-8FFAD5DECEEF

Type species. Xerasiborus euphorbiae sp. $\mathrm{n}$.

Diagnosis. Eye entire, short, oval. Antennal club smooth and shiny, with lateral tufts of setae. Funiculus 3-5 segmented. Pronotum dome-shaped, occasionally humpbacked, with large, rounded tubercles on anterior three-quarters or more, rarely with smaller sharp asperities; posterior margin of pronotum rounded, vestiture of mixed scale-and hairlike setae. Scutellum not visible. Elytral base has a fine rim. Interstrial setae erect, spatulate, in single rows; strial setae recumbent, short and hair-like. Setae on metanepisternum plumose or bifid, in row parallel to sclerolepidiae and continue as plumose scales on metepimeron and near anterior margin of metacoxae. Procoxae contiguous; mesocoxae widely separated.

Etymology. Greek, composed of the stem of the noun Xerasia, meaning dryness or drought, and the noun borus, meaning excessive feast, referring to the preferred development in dry wood in arid warm habitats. Gender masculine.

Distribution. Madagascar, Tanzania.

\section{Key to species}

1 Setae on middle of metanepisternum bristle-like, on metasternum and first abdominal ventrite mainly bifid; asperities on pronotum form large, rounded tubercles ............................... 2

- Setae on metanepisternum plumose scales, on metasternum and first abdominal ventrite trifid or plumose; asperities on pronotum either rounded or sharp ......

2 Anterior margin of pronotum with transverse row of four large tubercles; length $0.8-0.9 \mathrm{~mm}$ (Madagascar).....

Xerasiborus quadrituberculatus sp.
- Anterior margin of pronotum with two large prominent tubercles; length $0.7 \mathrm{~mm}$ (Madagascar)... .. Xerasiborus bituberculatus sp. $\mathrm{n}$.

3 Asperities on pronotum tuberculate, larger than antennal pedicel; setae on pronotum and elytra truncated (Tanzania).. Xerasiborus zambesianus sp. $\mathrm{n}$.

- Asperities normal, smaller than antennal pedicel; scale-like setae spatulate.

4 Pronotum humpbacked just behind middle, flat on posterior third; anterior margin of pronotum with two small asperities; recorded in succulent Euphorbia (Madagascar).

Xerasiborus euphorbiae sp. $\mathrm{n}$

Pronotum dome-shaped, summit on posterior third; anterior margin of pronotum with four small asperities (Madagascar)

Xerasiborus asperatus sp. $\mathrm{n}$.

\section{Xerasiborus quadrituberculatus sp. $\mathbf{n}$.}

Figs 31, 34, 37

ZooBank taxon LSID:

D2C2A8A7-E8A4-4D99-A2CE-E547C2A6E415

Diagnosis. Asperities on pronotum very large, four tubercles form an irregular transverse row along anterior margin; setae on metanepisternum bifid, near metacoxae plumose.

Description, male. Length $0.8-0.9 \mathrm{~mm}, 2.1-2.2 \times$ as long as wide. Colour dark brown. Head. Frons granulated on upper half and vertex, lower median half and epistoma smooth and shiny, impunctate; vestiture consisting of scattered, short, fine setae. Funiculus 3-segmented, pedicel much longer than segments 2-3 combined; club shiny, without sutures, slightly indented laterally with tufts of short setae. Eyes separated above by $2.8-3.2 \times$ their width. Pronotum dome-shaped, with huge, rounded asperities or tubercles present from near posterior margin to anterior margin, which has a transverse row of four tubercles. Vestiture of mixed hair-like and short spatulate setae. Elytral base has a fine rim, scutellum barely visible. Striae not impressed, punctures deep, in rows, separated on average by $2 \times$ their diameter; interstriae shiny, finely granulated; vestiture consisting of rows of short, slightly curved scalelike setae, and very fine, minute, recumbent strial setae. Ventral sclerites. Setae on metanepisternum in row along the sclerolepidia, plumose at anterior and posterior ends, bifid along most of its middle part. Legs. Protibiae with two small, socketed teeth along the lateral edge. Metatibiae with three socketed teeth on apical fourth.

Female. Identical to male.

Type material. Holotype, male?: Madagascar, Efoetsy, PN Tsimanampetsotsa [-24.051, 43.763], 18 March 2002, sifted litter, BLF6160, B. Fischer, leg. Paratypes: same data as holotype (9). Holotype and five paratypes in CAS, two paratypes each in ZMUB and NHMW.

Type locality. Madagascar, Atsimo-Andrefana region, Efoetsy.

Etymology. Latin, from quadrum, meaning four, and tuberculatus, a masculine nominative adjective meaning tuberculate, referring to the four large tubercles on the anterior margin of the pronotum.

Distribution. Madagascar. Only known from the type locality in the southern lowlands on the island. 


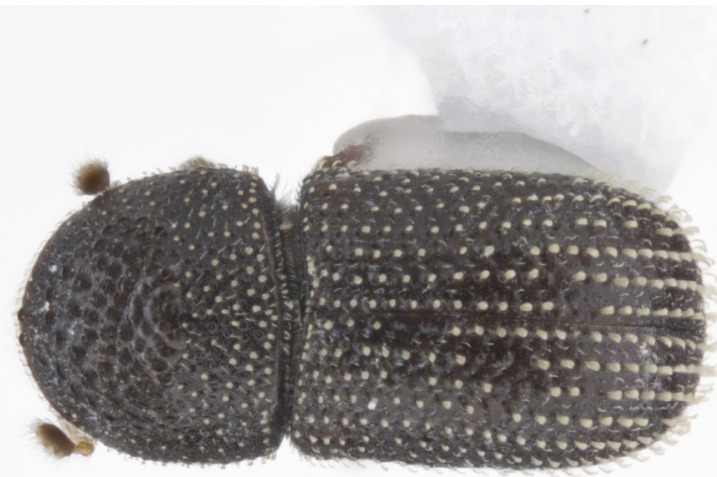

40
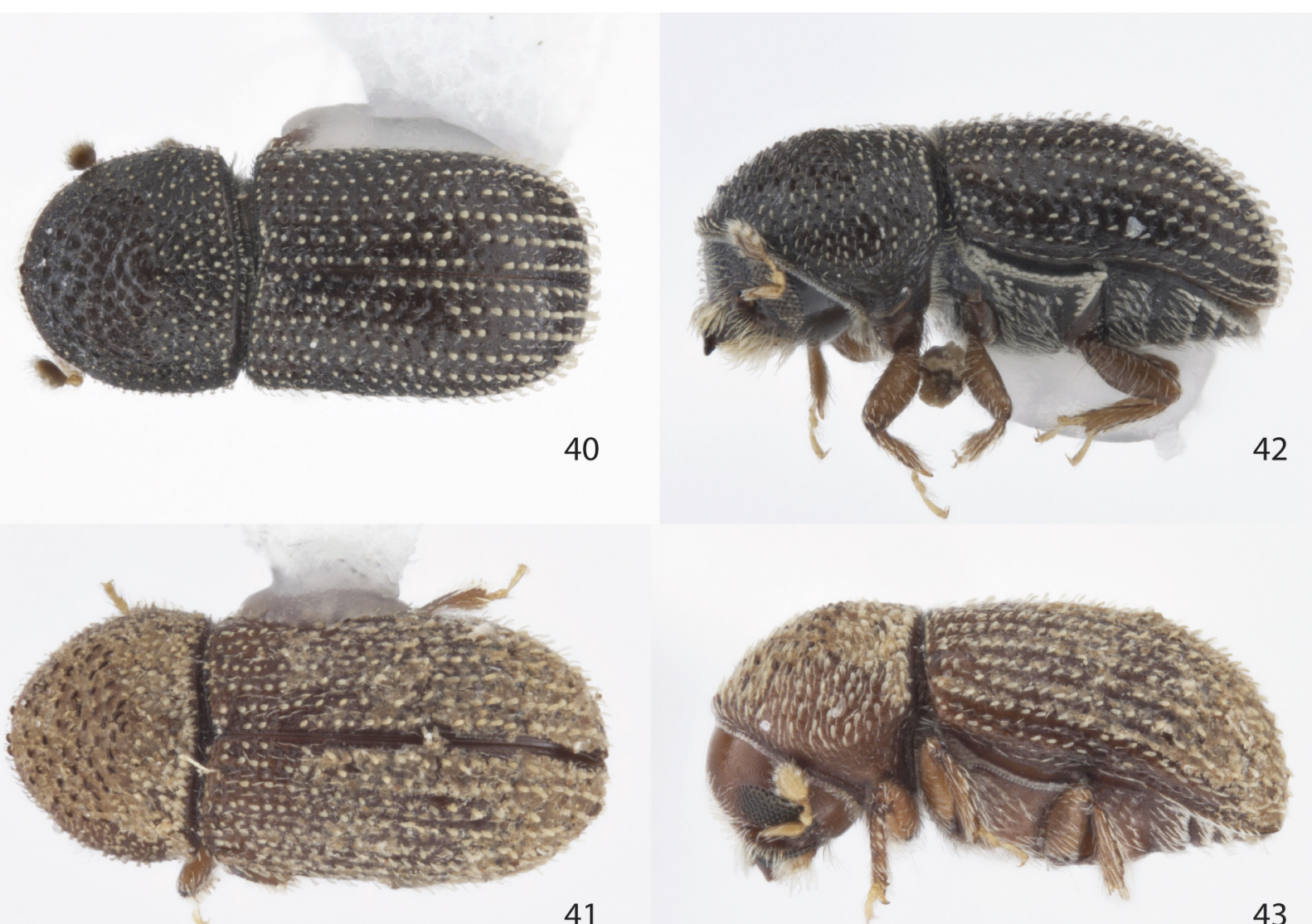

41
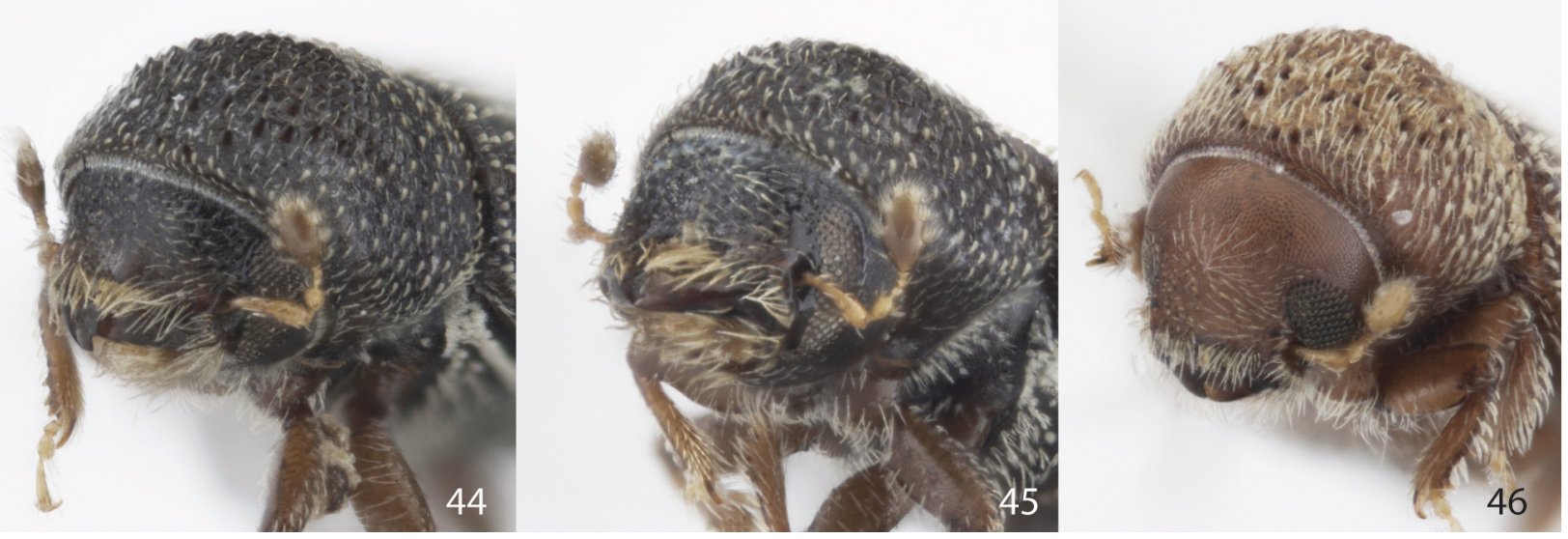

Figs 40-46. Dorsal, lateral and front view of Xerasiborus. 40, 42, 44 - Xerasiborus euphorbiae, female holotype; $45-X$. euphorbiae, male paratype, frons; $41,43,46$ - Xerasiborus asperatus, holotype.

Remarks. Can be distinguished from the closely related $X$. bituberculatus sp. n. (described below) by the four tubercles on the anterior margin of the pronotum, the continuous distribution of other asperities, the more broadly separated eyes and its slightly larger body size. Both species were found in sifted litter of dry shrub vegetation, in two nearby localities together with an equally tiny species of Microlanurgus Jordal, 2021.

\section{Xerasiborus bituberculatus sp. $\mathrm{n}$.}

Figs 32, 35, 38

ZooBank taxon LSID:

8FE23AA2-44A8-4FBD-BE94-5D0819E9FEE5
Diagnosis. Asperities on pronotum very large, two enlarged tubercles on the anterior margin, with a short smooth gap between anterior margin and other asperities; setae on metanepisternum few, coarse, bifid, largely abraded or reduced, those adjacent to metacoxae plumose. Interstrial setae increase in size posteriorly, widely spaced.

Description, male? Length $0.7 \mathrm{~mm}, 2.1 \times$ as long as wide. Colour black. Head. Strongly reticulated, tiny longitudinal impression on median half; vestiture consisting of scant, short, fine setae. Funiculus 3-segmented, pedicel much longer than segments 2-3 combined; club shiny, without sutures, laterally lightly indented with tufts of short setae. Eyes separated above by $2.3 \times$ their width. Pronotum dome- 
shaped, strongly reticulated, with big, rounded asperities present from near posterior margin to anterior fifth, then a smooth gap to the anterior margin, on which there are two enlarged tubercles. Vestiture consisting of scant hair-like and bristle-like setae. Elytral base has a fine rim, scutellum minute, barely visible. Striae not impressed, punctures in rows, deep, large, on average separated by their diameter; interstriae finely rugose, shiny; vestiture consisting of uniseriate interstrial rows of short, curved spatulate setae increasing in size posteriorly, spaced at 3-5× their length, and very fine minute, semirecumbent strial setae. Ventral sclerites. Setae on metanepisternum largely abraded or reduced, a few plumose setae just anterior to the metacoxae. Legs. Protibiae with two small, socketed teeth along the lateral edge. Metatibiae with three socketed teeth laterally on apical fourth.

Type material. Holotype, male?: Madagascar, Mahafaly Plateau, $6.2 \mathrm{~km} 74 \mathrm{deg}$ ENE Itampolo [-24.627, 44.077], in sifted litter, BLF5758, B. Fischer, leg. Holotype deposited in CAS.

Type locality. Madagascar, Atsimo-Andrefana region, Itampolo.

Etymology. Composed of the Latin prefix $b i$-, meaning two (parts), and tuberculatus (see above), referring to the two large tubercles on the anterior margin of the pronotum.

Distribution. Madagascar. Only known from the type locality in the southern lowlands on the island.

\section{Xerasiborus zambesianus sp. $\mathbf{n}$.}

Figs 33, 36, 39

ZooBank taxon LSID:

E1956EFC-FEB0-45E2-94D7-A482841E7288

Diagnosis. Asperities on pronotum very large, broad, anterior margin with transverse row of four large asperities; setae on metanepisternum large, plumose; pronotal and interstrial setae truncated.

Description, male. Length $0.9-1.1 \mathrm{~mm}, 2.2-2.5 \times$ as long as wide. Colour brown to dark brown. Head. Frons convex, surface reticulated; vestiture consisting of fine short setae, which are more densely spaced on epistoma. Funiculus 4-segmented, pedicel as long as segments 2-4 combined; club shiny, without sutures, lightly indented laterally with tufts of short setae. Eyes separated above by $1.7-1.9 \times$ their width. Pronotum dome-shaped, anterior three-quarters shiny with large sharp asperities, anterior margin with row of four large asperities. Vestiture consisting of mixed hair-like and scale-like setae. Elytral base has a sharp rim, scutellum barely visible. Striae weakly impressed, punctures small, lightly impressed, in rows, on average separated by $1-1.5 \times$ their diameter; interstriae shiny, finely and increasingly granulated posteriorly; vestiture consisting of rows of short, erect, truncated scale-like setae and very fine, minute, recumbent strial setae. Ventral sclerites. Setae on metanepisternum broadly plumose, densely spaced in a row; setae elsewhere mixed but mainly trifid. Legs. Protibiae with three small, socketed teeth along the lateral edge. Metatibiae laterally with four socketed teeth on apical third.

Female. Identical to male.
Type material. Holotype, male?: Tanzania, Morogoro Province, Sanje, GIS: -7.793, 36.897, ex twig of shrub [2vii-6], 2. July 2010, B. Jordal, leg. Paratypes: same data as holotype (4). Holotype and two paratypes deposited in ZMUB, two paratypes in NHMW.

Type locality. Tanzania, Morogoro province, Sanje.

Etymology. Named after the Zambesian biogeographical region, with the Latin suffix -anus to create a masculine nominative adjective, meaning origin in, or possession of, Zambesi.

Distribution. Tanzania, Udzungwa Mountains.

Remarks. Although this is the only species in this genus known from the African mainland, and the molecular data place it as a sister to the two included species from Madagascar, it is a typical Xerasiborus within the acceptable genetic and morphological variation for this genus.

\section{Xerasiborus euphorbiae sp. $\mathbf{n}$.}

Figs 40, 42, 44, 45

ZooBank taxon LSID:

A61F7F4B-B957-4196-AE6D-727E8F5DA980

Diagnosis. Asperities on pronotum not larger than the antennal pedicel, anterior margin with two small asperities; setae on metanepisternum large, plumose; pronotal and interstrial setae mainly spatulate.

Description, female. Length $1.2-1.3 \mathrm{~mm}, 2.3-2.5 \times$ as long as wide. Colour dark brown to black, legs slightly lighter. Head. Frons convex above, increasingly impressed and shiny from upper level of eyes to epistoma, granuloreticulate elsewhere, with a tiny smooth callus just above epistoma; vestiture consisting of fine short setae, which are more densely spaced on epistoma. Funiculus 4-segmented, segments 2-4 combined slightly longer than pedicel; club shiny, without sutures, lightly indented laterally with tufts of short setae. Eyes separated above by $3.2-3.5 \times$ their width. Pronotum humpbacked, summit just behind middle, surface sub shiny, reticulated, anterior margin with two small asperities, on anterior three-quarters with densely spaced coarse asperities, finely granulo-punctate elsewhere. Vestiture consisting of mixed hair-like and spatulate scale-like setae. Elytral base has a sharp rim, scutellum barely visible. Striae not impressed, punctures very small, in rows, separated by $3-5 \times$ their diameter; interstriae shiny, granulated; vestiture consisting of rows of curved, spatulate setae, spaced apart by a distance equal to their length, slightly longer and more densely spaced on the declivity, and very fine, minute, recumbent strial setae. Ventral sclerites. Setae on metanepisternum broadly plumose, densely spaced in mainly a single row; setae elsewhere mixed, mainly plumose and trifid, some bifid. Legs. Protibiae with three small, socketed teeth along the lateral edge. Metatibiae with four socketed teeth on apical third.

Male. Similar to female except lower frons more strongly impressed and mandibles are distinctly prognathous.

Type material. Holotype, female: Madagascar, Diana region, Ankarana National Park, 50 m alt., GIS: -12.96, 49.12. Ex Euphorbia tirucalli, 2019: 30x-2, B. Jordal, leg. Paratypes (3): same data as holotype. Holotype and one paratype deposited in ZMUB, one paratype each in NHMW and ZUAC. 
Type locality. Madagascar, Diana region, Ankarana.

Etymology. Named after the host plant genus Euphorbia as noun in apposition.

Distribution. Madagascar.

Remarks. Only known from the type locality at Ankarana, Madagascar. This species breeds in recently dead branches of Euphorbia tirucalli in sun exposed, hot places. Egg galleries were rather irregular and confluent. When suitable, most parts of a dead branch were eaten and the species is therefore likely to be abundant where the host plant occurs. This is the only species in this genus in which the frons is distinctly sexually dimorphic.

\section{Xerasiborus asperatus sp. $\mathbf{n}$.}

Figs 41, 43, 46

ZooBank taxon LSID:

4CB6EA3B-A70F-4F3F-ACDF-44523D9ADBE3

Diagnosis. Asperities on pronotum sharp, smaller than the antennal pedicel, anterior margin with transverse row of four small asperities; antennal funiculus 5-segmented; setae on metanepisternum large, plumose; pronotal and interstrial setae erect, narrowly spatulate.

Description, male. Length $1.1-1.3 \mathrm{~mm}, 2.2-2.3 \times$ as long as wide. Colour brown. Head. Frons convex above, flat on lower half, finely reticulate, dull; vestiture consisting of fine short setae except for a few coarse intermixed setae, on epistoma more densely spaced. Funiculus 5-segmented, segments 2-5 combined longer than pedicel; club shiny, without sutures, lightly indented laterally with tufts of short setae. Eyes separated above by $2.1-2.3 \times$ their width. Pronotum dome-shaped, summit just behind middle, surface granulo-punctate, anterior margin with row of four small asperities, on anterior three-quarters densely spaced, square, sharp asperities. Vestiture consisting of mixed hairlike and spatulate setae. Elytral base a thin irregular rim, scutellum barely visible. Striae not impressed, punctures small, deep, in irregular rows, separated by their diameter; interstriae shiny, finely rugose; vestiture consisting of rows of erect, spatulate setae, each separated by slightly less than their length, and very fine, recumbent strial setae, each slightly longer than distance between setae. Ventral sclerites. Setae on metanepisternum broadly plumose, mainly in a single row; setae elsewhere mixed plumose, trifid and bifid. Legs. Protibiae with three small, socketed teeth along the lateral edge. Metatibiae with four socketed teeth on apical third.

Female. Not identified, presumably identical to male in external characters.

Type material. Holotype: Madagascar [Diana region], Reserve Spéciale d'Ambre, $3.5 \mathrm{~km}$ SW Sakaramy [GIS: -12.464, 49.231; altitude $450 \mathrm{~m}$ ], sifted litter, BLF2564 [20-26 Jan 2001], B. Fischer, leg. Paratypes (2): same data as holotype. Holotype and one paratype deposited in CAS, one paratype in ZMUB.

Type locality. Madagascar, Diana region, Mt. d'Ambre.

Etymology. The name asperatus is a masculine nominative participle, meaning roughened, referring to the sharp asperities on the pronotum.

Distribution. Madagascar (see Fig. 47).

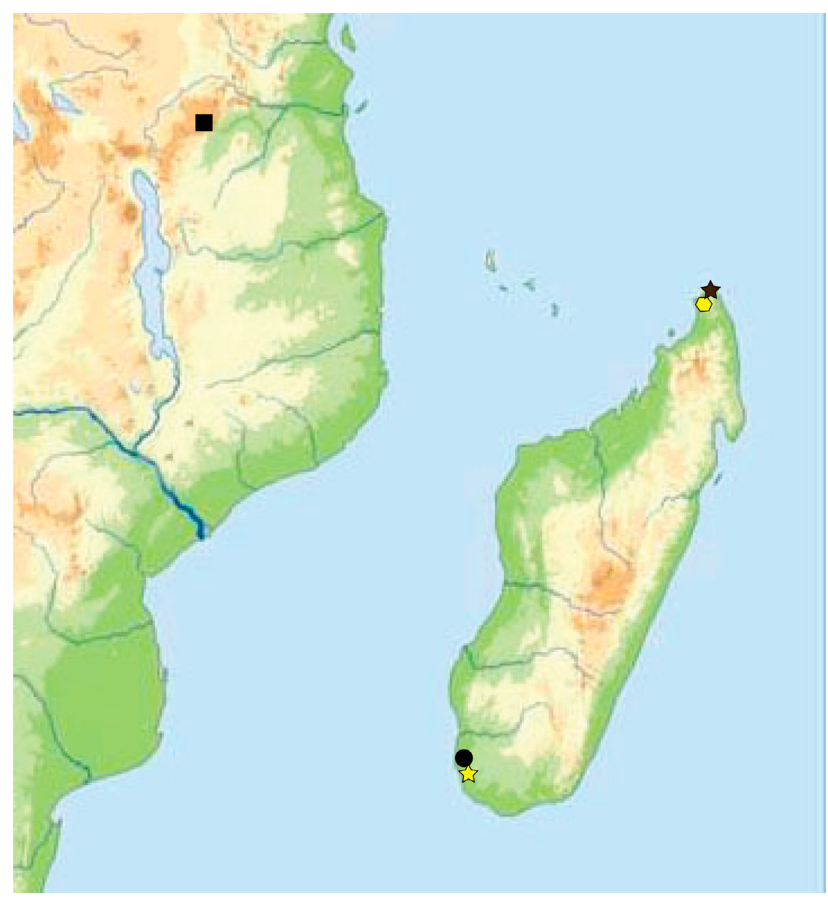

Fig. 47. Distribution of Xerasiborus in the Afrotropical realm. Black square $-X$. zambesianus; black star $-X$. asperatus; yellow circle $X$. euphorbiae; black circle $-X$. quadrituberculatus; yellow star $-X$. bituberculatus.

Remarks. Only known from the type locality near Montagne d'Ambre, Madagascar where it was sifted from leaf litter.

\section{Genus Nisiborus gen. $\mathbf{n}$.}

ZooBank taxon LSID:

8FCAB21A-74BB-46FA-831C-F8B2E09DEE2B

Type species. Ptilopodius hylesiniformis Schedl, 1961.

Diagnosis. Eyes entire, short, oval. Scapus elongated, much longer than funiculus; funiculus 4-segmented; club flattened, smooth and glabrous, lateral margins somewhat irregular, terminally with a suture that is only visible when viewed from above or behind. Pronotum finely asperate, posterior margin rounded, vestiture consisting of mixed hair-like or mixed scale- and hair-like setae. Scutellum very small, barely visible. Elytral base with a low irregular rim; interstrial setae scale- or hair-like, in single rows, strial setae fine to coarse, recumbent, variably in rows or confused. Procoxae contiguous; metacoxae broadly separated. Protibiae narrow, with 3 socketed teeth on the lateral margin, the inner mucro rather long, curved posterolaterally; meso- and metatibiae narrow, with 4 socketed teeth laterally on apical one-third. Setae on metanepisternum characteristically scale-like or plumose, running in a parallel line to the sclerolepidia, posteriorly turning dorsally on the epimeron and usually also ventrally just anterior to the metacoxa. Hindwings with 5 setae in cluster on subcosta, pterostigma (radial cell) with two setae. Proventriculus with apical plate much longer than posterior plate, median suture open, with tubercles along its inner margin; apical teeth absent, closing teeth short and simple. Aedeagus dorsoventrally curved, apophyses as long as aedeagal body; 

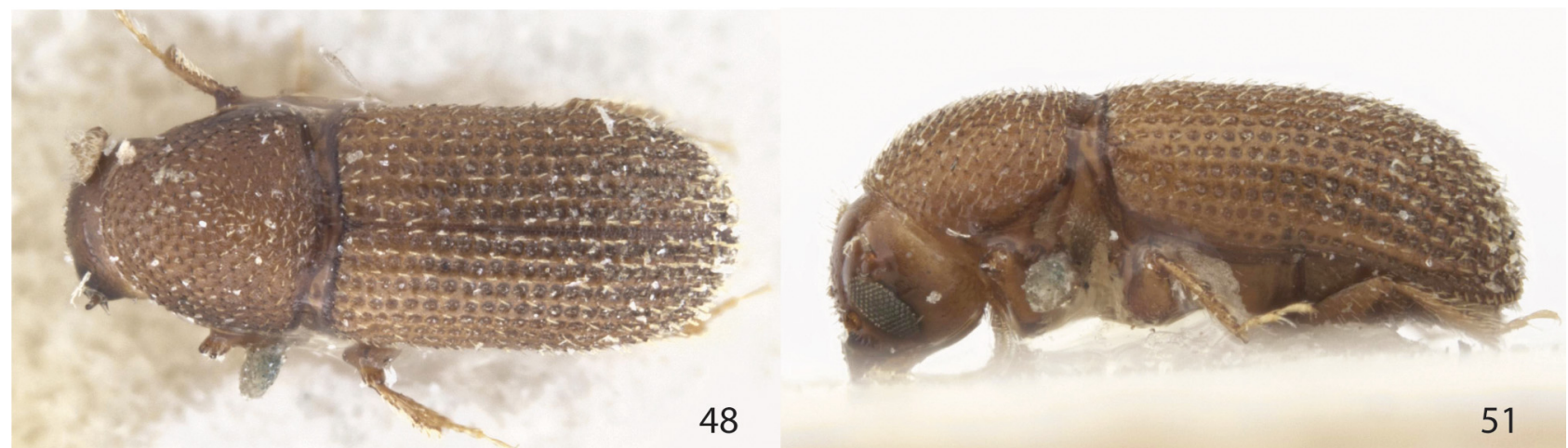

48

49

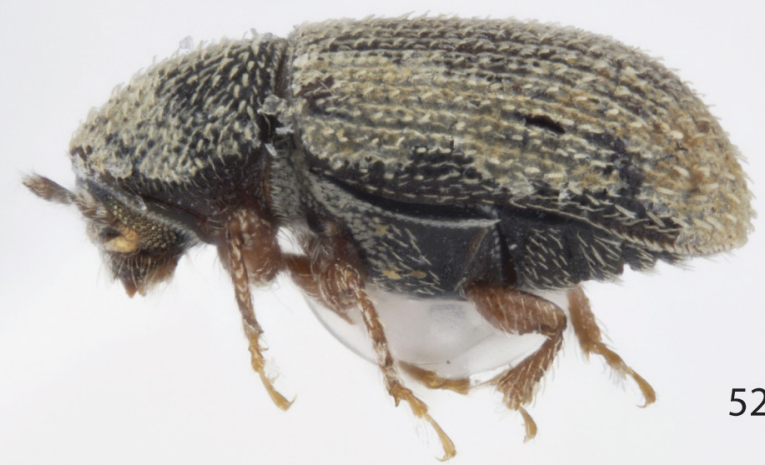

52
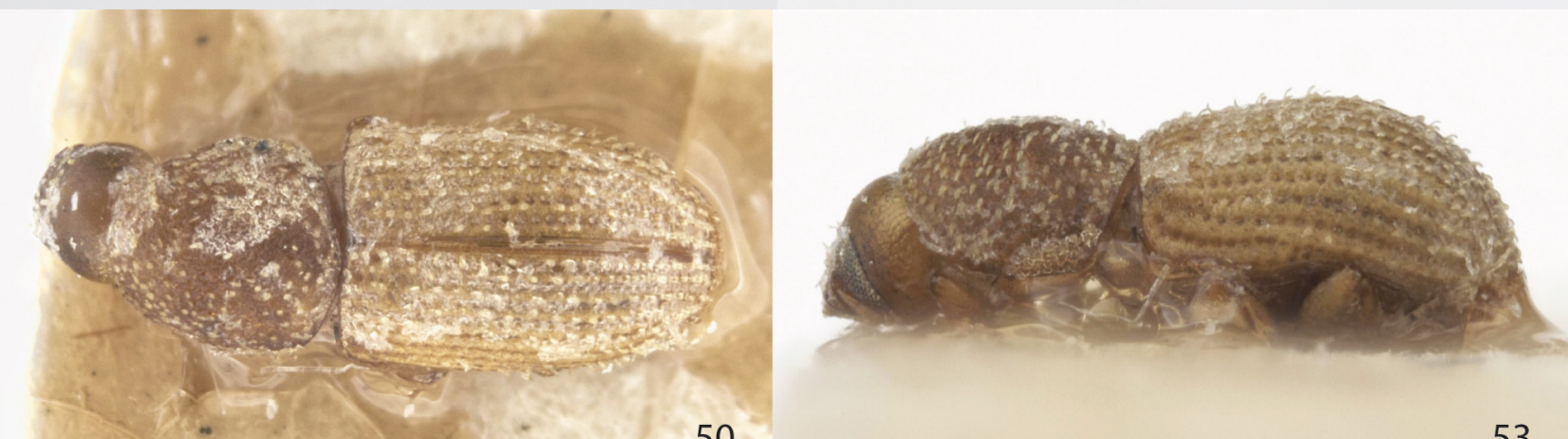

50

53

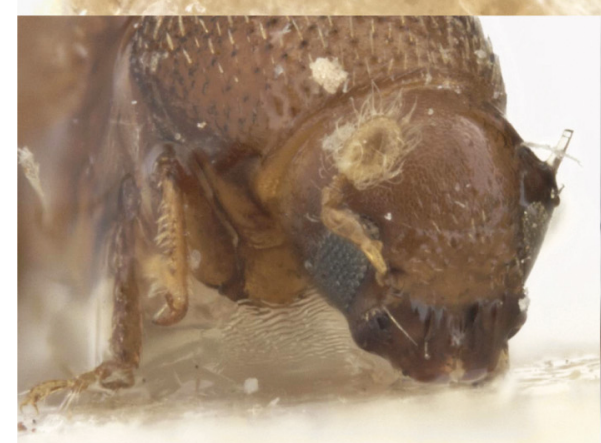

54

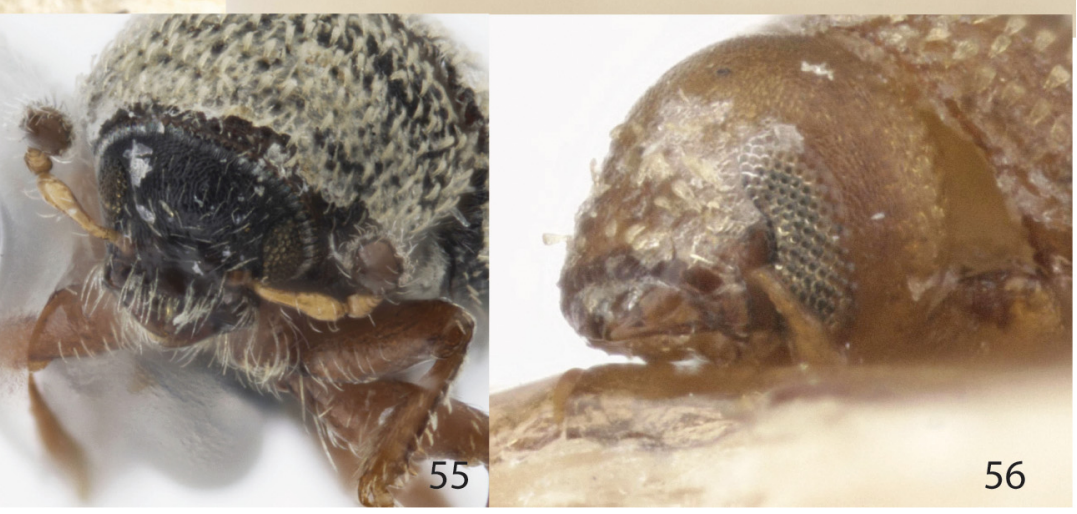

Figs 48-56. Dorsal, lateral and front view of Nisiborus and Cryphyophthorus holotypes. 48, 51, 54 - Nisiborus hylesiniformis; 49, 52, 55 - Nisiborus schaufussi; 50, 53, 56 - Cryphyophthorus eggersi.

tegmen a closed ring, manubrium long, curved; spiculum gastrale a simple rod.

Etymology. Greek, composed of the noun nisi, meaning island, and the noun borus, meaning glutton or extravagant feast, or in a wider context also used for excavating wood, referring to the endemic distribution on Madagascar, apparently thriving in small pieces of woody plant tissue. Gender masculine.

Included species: Nisiborus hylesiniformis (Schedl, 1961), Nisiborus schaufussi sp. n. 
Distribution. Madagascar.

Remarks. The type species was originally placed in Cryphyophthorus Schedl. However, the type species of Cryphyophthorus differs from Nisiborus in having sinuate eyes, sharp rim along the posterior margin of the pronotum, pronotal surface not strongly asperate, scutellum moderately large and visible and flush with the elytra, protibiae broad apically with two large socketed teeth, and striae lack minute setae. These differences require a new genus for Cryphyophthorus hylesiniformis (Schedl, 1961) and one undescribed species. They are closely related to Xerasiborus, but distinguished from that genus mainly by the broader distribution of much smaller asperities on the pronotum, and the longer and more evenly distributed sparse setae along the lateral margin of the antennal club.

\section{Key to species}

1 All setae on pronotum hair-like; interstrial ground vestiture absent, strial setae minute, scattered in rows.

.. Nisiborus hylesiniformis

- Pronotal setae mixed hair-like and scale-like; interstrial ground vestiture similar to strial setae.

.Nisiborus schaufussi sp. n.

Nisiborus hylesiniformis (Schedl, 1961), comb. $\mathbf{n}$.

Figs 48, 51, 54

Ptilopodius hylesiniformis Schedl, 1961.

Ernoporus hylesiniformis: Schedl, 1977.

Cryphyophthorus hylesiniformis: Wood \& Bright, 1992.

Diagnosis. Antennal club shiny, nearly glabrous; pronotum with fine asperities and hair-like setae; setae on elytral striae very fine, hair-like, in regular rows.

Redescription of male. Length $1.3-1.7 \mathrm{~mm}, 2.5-2.6 \times$ as long as wide. Colour light brown. Frons convex, triangularly impressed from epistoma to level of antennal insertion; eye entire, separated above by $2.2-2.3 \times$ their width; scapus elongated; funiculus 4-segmented, segments $2-4$ as long as the pedicel; club smooth and shiny, with 3-4 long, thin setae on disc, laterally with many more setae, posterior side with terminal suture. Pronotum gently rounded, finely asperate, reticulate, sub shiny; basal and lateral margins rounded; vestiture consisting of hair-like setae. Scutellum barely visible and only in anterior view. Elytral base finely crested; striae not impressed, punctures deep, sub contiguous; interstriae finely granulated; vestiture consisting of narrowly spatulate interstrial setae, and very fine strial and interstrial setae. Legs. Procoxae contiguous, mesocoxae broadly separated. Protibiae characteristically marked on inner margin by a broad indentation associated with dense, rigid setae above; lateral margin with 3 socketed teeth, the inner mucro long, curved posterio-laterally; metatibiae with 4 thin lateral teeth on apical third. Ventral sclerites. Metanepisternum with row of broad scale-like setae parallel to, and contiguous with, sclerolepidia.

Female. Externally identical to male.

Type material. Madagascar, Montagne d'Ambre, 4.xii.1952, Dr KE Schedl. Holotype in MNHN and one paratype in NHMW, both examined.

Distribution. Madagascar.
New record: Madagascar, Diana region, Montagne d'Ambre Nat. Park, $800 \mathrm{~m}$ alt, GIS: -12.54, 49.17, ex Ficus branch, 3.xi.2019 (\#E5), J. Eliassen, leg. (10 in ZMUB; 2 in ZUAC).

Remarks. This is the first host record for this species, which was dissected from a thin branch of a fig tree.

\section{Nisiborus schaufussi sp. $\mathbf{n}$.}

Figs 49, 52, 55

ZooBank taxon LSID:

AFB4D4B9-F7AB-4A80-8E82-3DF7F17E30A1

Diagnosis. Antennal club shiny, nearly glabrous, pronotum with fine asperities. Distinguished from N. hylesiniformis by the coarse and sub-plumose strial setae which are more densely placed and in part confused, by the intermixed scale-like setae on pronotum and the more broadly distributed plumose scales on the anterior part of the metaventrite.

Description, male. Length $1.2 \mathrm{~mm}, 2.3 \times$ as long as wide. Colour dark brown to black, setae yellowish white. Frons convex above, on central third just above epistoma a smooth and shiny groove; eye entire, separated above by $2.0 \times$ their width; scapus elongated; funiculus 4 -segmented, segments 2-4 as long as the pedicel; club smooth and shiny, with 3-4 long, thin setae and many long lateral setae, posterior face with two irregular sutures near apex. Pronotum gently rounded, finely asperate, coarsely reticulated and granulated; basal margin rounded, lateral margins abrupt but not sharp; vestiture of mixed hair-like and scalelike setae. Scutellum not visible. Elytral base finely carinate, elytral apex very narrowly rounded; striae lightly impressed, punctures small; interstriae rugose and granulated, broader than striae; vestiture consisting of erect scale-like interstrial setae, and densely spaced recumbent sub-plumose strial and interstrial setae. Legs. Procoxae contiguous, mesocoxae broadly separated. Protibiae marked on its inner margin by a broad indentation associated with dense, rigid setae further above; lateral margin with 3 small socketed teeth, the inner mucro long, curved posterio-laterally; metatibiae with 4 thin lateral teeth on apical third. Ventral sclerites. Mesanepisternum with row of broad plumose setae parallel and contiguous with sclerolepidia.

Female. Not known, presumably similar to the male in external characters.

Type material. Holotype, male: Madagascar, PN Montagne d'Ambre, 12.2 km SSW Joffreville [GIS: -12.596, 49.159], sifted litter, BLF2808, B. Fischer, leg. Holotype deposited in CAS.

Type locality. Madagascar, Diana Region, Mt. d'Ambre.

Etymology. Named after the German entomologist Camillo Festivus Christian Schaufuss who described many species of Malagasy bark beetles.

Distribution. Madagascar.

Remarks. Two specimens were collected by sifting litter at the type locality, one of which was severely damaged and only used for studying internal structures.

\section{Genus Glochiphorus Strohmeyer, 1910}

Type species. Glochiphorus globosus Strohmeyer, 1910 (monotypic). 
Diagnosis. Length $1.5 \mathrm{~mm}, 1.3 \times$ as long as wide. Frons (sex?) strongly concave, antennal funiculus 5-segmented, segment 2 longer than pedicel; club flattened, as wide as long, with two broadly procurved sutures marked by setae; eyes entire, very elongated. Pronotum large, almost as long as elytra, wider than long; vestiture consisting of pale scales. Scutellum not visible. Elytral base with fine crest, elytra variegated, with interstrial setae short, scale-like and confused, and minute strial setae. Protibiae narrow, with four small, lateral teeth, inner mucro large, curved posterio-laterally.

Included species: Glochiphorus globosus Strohmeyer, 1910, Glochiphorus alienus Schedl, 1982.

Distribution. Madagascar, South Africa?

Remarks. The protibiae, eyes and basal rim of the elytra suggest placement in Hypoborini, more specifically Xerasiborina, but this must be regarded as highly tentative. Six missing characters in the morphological character matrix further reduces confidence in the deviant position in the morphological phylogeny (Fig. 2). The genus is distinguished from all hypoborines by the long segment 2 of the antennal funiculus and large flat club with broadly procurved sutures marked by setae. The diagnosis is based only on the type species. The second species included, $G$. alienus, has deviant features such as crenulations reaching the humeral angle and will possibly be removed when more specimens become available in the future.

\section{Notes on other genera and their relevance to the classification of Hypoborini \\ Tribus Hypoborini Nüsslin, 1911 \\ Genus Phloeotrypetus Wood, 1960 stat. res.}

Type species. Phloetrypetus palauensis Wood, 1960 (original designation).

Diagnosis. Antennal funiculus 5-segmented, last segment extended laterally; club shiny, nearly glabrous. Pronotum with fine asperities mainly on central two-thirds of anterior half. Scutellum not visible. Elytral base crenulated between interstriae 1-5; elytral vestiture consisting of erect interstrial bristle-like setae and short, fine strial setae. Setae on metanepisternum plumose, in a row parallel to the metepisternal suture.

Distribution. Palau. It is likely there are several undescribed species, all from SE Asia (A. Johnson, pers. comm.).

Remarks. Resurrected from the genus Liparthrum. Distinguished from Liparthrum, Corditarsus and Hypoborus by the more evenly distributed small asperities on the pronotum and shiny antennal club without sutures, and from Liparthrum and Hypoborus by the broader median suture on the proventriculus, and from Liparthrum by the 5-segmented antennal funiculus.

\section{Tribus Chaetophloeini trib. $\mathbf{n}$.}

ZooBank taxon LSID:

9872BA71-9D20-4ABB-AA12-BC53FE6F8910

Chaetophloeini Schedl, 1966; synonym of Hypoborini by Alonso-Zarazaga \& Lyal (2009), name unavailable (nomen nudum).
Type genus. Chateophloeus LeConte 1858 .

Diagnosis. As for the type genus.

\section{Genus Chaetophloeus LeConte, 1876}

Type species. Hylesinus hystrix LeConte, 1858 (monotypic).

Diagnosis. Eyes sinuate. Antennal scapus elongated, shorter than 5-segmented funiculus; club large, flattened, with three distinct transverse sutures. Pronotum with small lateral clusters of asperities; lateral margins and hypomeron with split setae. Scutellum not visible. Base of elytra crested between suture and interstriae 4 , teeth on interstriae 1 and 2 much longer than on 3 and 4 . Interstrial ground vestiture scale-like. Setae on metanepisternum, metaventrite and abdominal ventrites bifid. Procoxa contiguous; protibiae broad, lateral edge gently curved, with 6-8 lateral socketed teeth. Proventriculus without median suture on the anterior plate. Postnotum fused to metanotum. Scutoscutellar suture curved, deviating from the scutellar groove.

Distribution. Nearctic, northern Neotropics.

Remarks. The only similarity to Hypoborini is the elevated crest at the elytral base, but this character differs as the inner two teeth are much bigger than the other teeth. The body plan differs fundamentally as the postnotum is fused and the anterior plate of the proventriculus lacks a median suture. It has therefore been suggested on several occasions that this genus is unrelated to other Hypoborini (Nobuchi, 1969; Wood, 1986; Israelson, 1990). Molecular data has furthermore conclusively excluded Chaetophloeus from the Hypoborini (Jordal \& Cognato, 2012; Pistone et al., 2018) and the genus should therefore be placed in a separate tribe.

\section{Incertae sedis}

\section{Genus Cryphyophthorus Schedl, 1953}

Figs 50, 53, 56

Type species. Cryphyophthorus eggersi Schedl, 1953 (original designation).

Diagnosis. Length $1.3 \mathrm{~mm}, 2.5 \times$ as long as wide; colour light brown. Eyes broadly sinuate. Scapus elongate, funiculus 4-segmented; club egg-shaped. Pronotum finely granulated; basal margin and possibly the lateral margins carinate; pronotal vestiture consisting of spatulate setae. Scutellum visible, moderately large, flush with elytra. Base of elytra with a thin rim; striae impressed, as wide as interstriae, punctures deep, separated within the row by half their diameter; interstriae lightly raised; vestiture consisting of interstrial rows of spatulate setae, strial setae absent. Protibiae expanding apically with two lateral teeth near apex.

Excluded species: Ptilopodius hylesiniformis Schedl, 1961 (to Nisiborus gen. n. in Hypoborini: Xerasiborina).

Distribution. SE-Asia.

Remarks. The type species of this genus has several features not compatible with Hypoborini, including a sharp rim on the posterior margin of the pronotum, sinuate eyes and no strial setae on the elytra. According to the description (not visible on the pinned holotype), the protibiae 
widen towards apex. Furthermore, the pronotum is not asperate. In conclusion, this species is not congeneric with Nisiborus hylesiniformis or other hypoborine taxa. More material is needed to assess tribe membership, but it may belong to Trypophloeini or Ernoporini.

\section{Tribus Hylesinini Erichson, 1836 \\ Genus Zygophloeus Schedl, 1958}

Type species. Zygophloeus australis Schedl, 1958 (monotypic).

Diagnosis. Eyes entire. Antennal scapus elongated, funiculus 6-segmented, club conical, with 3 transverse sutures. Pronotum with a few asperities laterally; vestiture consisting of scale-like setae. Scutellum not visible. Elytral base procurved, crested on humeral angles by multiple rows of teeth; square locking teeth on mesal flange of elytra; elytral ground vestiture consisting of confused scale-like setae. Procoxae widely separated; protibiae expanding apically into a slightly hemispherical flange with 5 lateral socketed teeth. Setae on metanepisternum, metasternum and abdominal ventrites bifid or simple. Scutoscutellar suture runs parallel to the scutellar groove. Postnotum separated from mesonotum by a complete membrane.

\section{Distribution. Australia.}

New record. Zygophloeus australis: Australia, Queensland, Bunya Mountains $1100 \mathrm{~m}$ alt. [-26.86, 151.57], 18. Jan. 2000, B. Jordal, leg. (new state record) (two specimens, ZMUB).

Remarks. This species was previously only known from the type locality in New South Wales. It was collected for the first time from the state of Queensland where it was dissected from a branch of tree on the ground. Previous phylogenetic analyses placed Zygophloeus separate from Hypoborini (Jordal \& Cognato, 2012; Pistone et al., 2018). These analyses, and morphological characters, instead indicate some, albeit distant, affinity to the Australasian genera of Hylesinini, which are molecularly clearly separate from the Holarctic members of that tribe. Zygophloeus is therefore only tentatively placed in Hylesinini.

ACKNOWLEDGEMENTS. I would like to thank R. Beaver who initially identified some of the species included in this study. A. Cognato facilitated loan of specimens from California Academy of Sciences, which are stored intermittently at Michigan state University. Permits were granted from Direction Generale des Resources L'Environment et des Forêts Madagascar export permit No. 176N-EA11/MG19 and research permit 275/19/MEDD, from Cape Nature permit 2006-AAA-004-00062-0035, and COSTECH-Tanzania 2010. Many thanks to L. Lindblom and S. Mugu for technical assistance in the DNA laboratory, University of Bergen.

\section{REFERENCES}

Alonso-Zarazaga M.A. \& Lyal C.H.C. 2009: A catalogue of family and genus group names in Scolytinae and Platypodinae with nomenclatural remarks (Coleoptera: Curculionidae). Zootaxa 2258: 1-134.

Bouckaert R., Vaughan T.G., Barido-Sottani J., Duchêne S., Fourment M., Gavryushrina A., Heled J., Jones G., Kühnert D., De Maio N. et al. 2019: BEAST 2.5: An advanced software platform for Bayesian evolutionary analysis. - PLOS Comput. Biol. 15: e1006650, 28 pp.
BRIGHT D.E. 1981: Afrotrypetus, a new genus of bark beetles from Africa (Coleoptera: Scolytidae). — Coleopt. Bull. 35: 113-116.

ERICHSON W.F. 1836: Systematische Auseinandersetzung der Familie der Borkenkäfer (Bostrichidae). - Arch. Naturges. 2: 45-65.

HAACK R.A. 2001: Intercepted Scolytidae (Coleoptera) at U.S. ports of entry: 1985-2000. - Integr. Pest Manag. Rev. 6: 253-282.

IsRAELSON G. 1990: A key to the Macaronesian Hypoborini, with description of two new species (Coleoptera, Scolytidae). Bocagiana 137: 1-11.

Johnson A.J., McKenna D.D., Jordal B.H., Cognato A.I., Smith S.M., Lemmon A.R., Lemmon E.M. \& Hulcr J. 2018: Phylogenomics clarifies repeated evolutionary origins of inbreeding and fungus farming in bark beetles (Curculionidae, Scolytinae). - Mol. Phylogenet. Evol. 127: 229-238.

JoRDAL B.H. 2006: Community structure and reproductive biology in bark beetles (Coleoptera: Scolytinae) associated with Macaronesian Euphorbia shrubs. - Eur. J. Entomol. 103: 71-80.

JORDAL B.H. 2014: Scolytinae. In Leschen R. \& Beutel R. (eds): Handbook of Zoology. Arthropoda: Insecta. Coleoptera, Beetles, Vol. 3: Morphology and Systematics (Phytophaga). Walter de Gruyter, Berlin/Boston, pp. 633-642.

Jordal B.H. 2021: A phylogenetic and taxonomic assessment of Afrotropical Micracidini (Coleoptera, Scolytinae) reveals a strong diversifying role for Madagascar. - Org. Div. Evol. 21: 245-278.

Jordal B.H. \& Cognato A.I. 2012: Molecular phylogeny of bark and ambrosia beetles reveals multiple origins of fungus farming during periods of global warming. - BMC Evol. Biol. 12: 133, 10 pp.

Jordal B.H. \& Kaidel J. 2017: Phylogenetic analysis of Micracidini bark beetles (Coleoptera: Curculionidae) demonstrates a single trans-Atlantic disjunction and inclusion of Cactopinus in the New World clade. - Can. Entomol. 149: 8-25.

JoRdal B.H., KiRKENDAll L.R. \& Harkestad K. 2004: Phylogeny of a Macaronesian radiation: host-plant use and possible cryptic speciation in Liparthrum bark beetles. - Mol. Phylogenet. Evol. 31: 554-571.

LESCHEN R.A.B. \& Beutel R.G. (eds) 2014: Handbook of Zoology. Arthropoda: Insecta. Coleoptera, Beetles, Vol. 3: Morphology and Systematics (Phytophaga). Walter de Gruyter, Berlin/ Boston, xii $+675 \mathrm{pp}$.

Minh B.Q., Schmidt H.A., Chernomor O., Schrempf D., Woodhams M.D., von Haeseler A. \& LANFeAR R. 2020: IQ-TREE 2: New models and efficient methods for phylogenetic inference in the genomic era. - Mol. Biol. Evol. 37: 1530-1534.

Mugu S., Pistone D. \& Jordal B.H. 2018: New molecular markers resolve the phylogenetic position of the enigmatic woodboring weevils Platypodinae (Coleoptera: Curculionidae). Arthropod Phyl. Syst. 76: 45-58.

NoBuchi A. 1969: A comparative morphological study of the proventriculus in the adult of the subfamily Scolytoidea (Coleoptera). - Bull. Gov. For. Exp. St. 224: 39-110, pls 111-117.

Pistone D., Gohli J. \& Jordal B.H. 2018: Molecular phylogeny of bark and ambrosia beetles (Curculionidae: Scolytinae) based on 18 molecular markers. - Syst. Entomol. 43: 387-406.

Rambaut A., Drummond A.J., Xie D., Baele G. \& Suchard M.A. 2018: Posterior summarization in Bayesian phylogenetics using Tracer 1.7. - Syst Biol. 67: 901-904.

Ronquist F. \& HuELSENBECK J.P. 2003: MRBAYES 3: Bayesian phylogenetic inference under mixed models. - Bioinformatics 19: $1572-1574$ 
Schaufuss C.F.C. 1905: Borkenkaferstudien, II. - Insektenborse 12: $1-104$.

SCHEDL K.E. 1953: Fauna Indomalayensis. III. Contribution 133 to the morphology and taxonomy of the Scolytoidea. - Ann. Mag. Nat. Hist. 12: 288-304.

SchedL K.E. 1958: Some more bark- and timber-beetles from Australia. 158. Contribution to the morphology and taxonomy of the Scolytoidea. — Proc. Linn. Soc. N.S.W. 83: 214-216.

SCHEDL K.E. 1961: Fauna Madagascariensis, IV. 188. Contribution à la morphologie et à la systématique des coléoptères Scolytoidea. — Mém. Inst. Sci. Madag. (Sér. E) 12: 127-170.

SCHEDL K.E. 1966: Interessante und neue Scolytoidea aus Afrika. 244. Beitrag zur Morphologie und Systematik der Scolytoidea. — Rev. Entomol. Moçambique 8[1965]: 349-379.

SCHEDL K.E. 1972: Scolytoidea aus Tanganyika. 285. Beitrag zur Morphologie und Systematik der Scolytoidea (Coleoptera). Ann. Hist.-Nat. Mus. Natn. Hung. 64: 295-297.

SCHEDL K.E. 1975: South African bark and timber beetles, 3. 297. Contribution to the morphology and taxonomy of the Scolytoidea. - Ann. Transvaal Mus. 29: 275-281.

SCHedL K.E. 1977: Die Scolytidae und Platypodidae Madagaskars und einiger naheliegender Inselgruppen. - Mitt. Forstl. Bund-Vers. (Wien) 119: 1-326.
Swofford D. 2002: PAUP*. Phylogenetic Analysis Using Parsimony (*and other Methods). Ver. 4. Sinauer Associates, Sunderland, MS.

Wollaston T.V. 1854: Insecta Maderensia, Being an Account of the Insects of the Islands of the Madeiran Group. Van Voorst, London, $634 \mathrm{pp}$.

Wood S.L. 1960: Coleoptera: Platypodidae and Scolytidae. Insects of Micronesia 18: 1-73.

Wood S.L. 1962. Miscellaneous taxonomic notes on Scolytidae (Coleoptera). - Great Basin Nat. 22: 76-82.

Wood S.L. 1983: New synonomy and new species of American bark beetles (Coleoptera: Scolytidae), part IX. - Great Basin Nat. 43: 647-659.

Wood S.L. 1986: A reclassification of the genera of Scolytidae (Coleoptera). - Great Basin Nat. Mem. 10(Article 2): 1-110.

Wood S.L. \& BRight D. 1992: A catalog of Scolytidae and Platypodidae (Coleoptera). Part 2: Taxonomic index. - Great Basin Nat. Mem. 13: 1-1553.

Yu Y., Blair C. \& He X.J. 2020: RASP 4: ancestral state reconstruction tool for multiple genes and characters. - Mol. Biol. Evol. 37: 604-606.

Received October 6, 2020; revised and accepted February 8, 2021 Published online March 26, 2021 